\title{
New records of continental cyclopids (Crustacea: Copepoda: Cyclopiformes) from Eastern Siberia and Russian Far East
}

\author{
Новые находки континентальных щиклопид (Crustacea: \\ Copepoda: Cyclopiformes) из Восточной Сибири \\ и Аальнего Востока России
}

\author{
Victor R. Alekseev, Olga A. Chaban \\ B.P. Алексеев, О.А. Чабан
}

Zoological Institute RAS, St. Petersburg 199034, Russia. E-mail: alekseev@zin.ru

Зоологический институт РАН, Санкт-Петербург 199034, Россия.

KEY WORDS: biodiversity, aquatic invertebrates, copepods, Tethys Sea, climatic factor, range expansion, Cyclops, Ectocyclops, Eucyclops, Megacyclops, Mesocyclops.

КЛЮЧЕВЫЕ СЛОВА: биоразнообразие, водные беспозвоночные, веслоногие раки, море Тетис, климатический фактор, расширение ареалов, Cyclops, Ectocyclops, Eucyclops, Megacyclops, Mesocyclops.

ABSTRACT. A brief description of morphological features of 7 species of cyclopids new to the fauna of Russia from the water bodies of Eastern Siberia (Eucyclops (Speratocyclops) dumonti Alekseev, 2000, Ectocyclops polyspinosus Harada, 1931, Cyclops borealis Lindberg, 1956), Primorsky Krai (E. (E.) agiloides roseus Ishida, 1997, Megacyclops magnus (Marsh, 1920), Mesocyclops (Pilosomesocyclops) mariae Guo, 2000) and Kamchatka (Eucyclops (Denticyclops) euacanthus (Sars, 1909)) is given. E. (S.) dumonti was described from Mongolia, then found in North China and its finding in small lakes of Transbaikalia was quite expected. Most of the remaining species new to our fauna were either also described from neighboring countries (China, Taiwan, Japan), or had already been found there earlier (South Korea). The type habitat of two species of the genus Eucyclops belonging to different subgenera, E. (D.) euacanthus and E. (E.) agiloides is Equatorial Africa (Lake Tanganyika), and the modern range covers the tropical and subtropical regions of the Old World and, possibly, Australia. The occurrence of $E$. agiloides and E. euacanthus in Primorsky Krai and Kamchatka represents the northernmost borders of the eastern part of their ranges and, possibly, reflects the tendencies of their expansion, caused by the evolution of the last period of the Tethys Sea. Ectocyclops polyspinosus, described from the island of Taiwan, was later found in some countries of Southeast Asia and in Canada. Finding it in the Baikal region and Primorsky Krai, apparently, falls on the most western and northern parts of its range, covering the SinoMalay part of the Palaearctic. Two more species of cyclopids (Mesocyclops (Pilosomesocyclops) dissimilis Defaye et Kawabata, 1993 and M. (M.) pehpeiensis $\mathrm{Hu}, 1943$ ) have already been encountered and their second finds confirm their presence in the fauna of the country and expand the areas of their distribution.

How to cite this paper: Alekseev V.R., Chaban O.A. 2021. New records of continental cyclopids (Crustacea: Copepoda: Cyclopiformes) from Eastern Siberia and Russian Far East // Arthropoda Selecta. Vol.30. No.4. P.503-520. doi: 10.15298/arthsel.30.4.06

РЕЗЮМЕ. Приведено краткое описание морфологии 7 новых для фауны России видов циклопид из водоемов Восточной Сибири (Eucyclops (Speratocyclops) dumonti Alekseev, 2000; Ectocyclops polyspinosus Harada, 1931, Cyclops borealis Lindberg, 1956), Приморского края (E. (E.) agiloides roseus Ishida, 1997, Megacyclops magnus (Marsh, 1920), Mesocyclops (Pilosomesocyclops) mariae Guo, 2000) и Камчатки (Eucyclops (Denticyclops) euacanthus (Sars, 1909)). E. (S.) dumonti был описан из Монголии, затем найден в Северном Китае, и нахождение его в мелких озерах Прибайкалье было вполне ожидаемо. Большинство остальных новых для нашей фауны видов были либо также описаны из соседних стран (Китая Тайваня, Японии), либо уже встречены там (Южная Корея). Типовым местом обитания двух видов рода Eucyclops относящихся к разным подродам, E. (D.) euacanthus и $E$. (E.) agiloides, является Экваториальная Африка (озеро Танганьика), а современный ареал охватывает тропическую и субтропическую области Старого Света и, возможно, Австралию. Нахождение Еисусlops agiloides и E. euacanthus в России представляет собой самые северные края восточной части их ареалов и, возможно, отражает тенденции их расширения, обусловленные эволюцией последнего периода существования моря Тетис. Ectocyclops polyspinosus, описанный с острова Тайвань, позднее был найден в некоторых странах Юго-Восточной 
Азии и в Канаде. Находка его в Прибайкалье и Приморском Крае, по-видимому, приходится на наиболее западную и северную части его ареала, охватывающего Сино-Малайскую часть Палеарктики. Еще два вида циклопид (Mesocyclops (Pilosomesocyclops) dissimilis Defaye et Kawabata, 1993 и M. (M.) pehpeiensis Hu, 1943) ранее уже были встречены на Дальнем Востоке и являются вторыми находками, подтверждающими их присутствие в фауне страны и расширяющими ареалы их распространения.

\section{Introduction}

The fauna of copepods of continental water bodies of the eastern regions of Russia and neighboring countries is far from being studied sufficiently. This is explained not only by the vastness of the territory and its remoteness from academic centers, but also by its originality and notorious difference from the European and West Siberian regions. The territory of Beringia (to the east of the Lena River) was never covered by an ice sheet, which favored speciation. The Amur River and its watershed, including relict remains of freshwater areas of the last period of the Tethys Sea, are part of the species-rich Sino-Indian province of Southeast Asia - one of the largest center of species diversity of aquatic and terrestrial organisms on the planet along with the Amazon River. Due to some problems of this area, including geopolitical, it remains largely not yet covered by modern studies of biodiversity. The biological diversity or species composition of the copepod fauna of modern Russia is continuously being clarified both through revisions common to the country and by specifying regional faunas [Rylov, 1948; Mazepova, 1978; Monchenko, 1974; Alekseev, 1998, 2015, 2019, 2020]. This can be explained by the description of new species, clarification or change of species names, the study of new areas, especially such as Baikal or the Caspian Sea, characterized by high faunistic endemism [Mazepova, 1978; Monchenko, 2003]. A special place in this process of faunistic revision is occupied by the finding of new species for the country, since it not only expands knowledge about their ranges, but can also indicate their change under the influence of tectonic, climatic and anthropogenic processes, such as biological invasions. This communication is devoted to the records and descriptions of several cyclopid species new for the fauna of Russia of the genera Cyclops, Ectocyclops, Eucyclops, Megacyclops, Mesocyclops in the water bodies of Eastern Siberia and the Far East.

\section{Material and methods}

The work used mainly materials collected by the authors personally during expeditions to Eastern Siberia and the Far East in 2006-2021. In three cases, the material for identification was kindly presented to us by colleagues from the Far East Center of Russian Academy of Science, Limnological Institute of the Russian Academy of Sciences and from the University of Ghent, Belgium.
Samples were collected by classical methods accepted in freshwater hydrobiology: by plankton net with a diameter of $26 \mathrm{~cm}$, mesh size $100 \mathrm{~mm}$, from the bottom to the surface vertically from a boat or diagonally from the shore, usually in 3 replicates merged into one sample, littoral fauna were collected with a hydrobiological triangular hand net made of the same netting, by ten mows $1 \mathrm{~m}$ each above the bottom sediments and/or among vegetation; the samples were preserved with $85-90 \%$ ethanol or $2-4 \%$ formalin. The primary processing of the samples was carried out under a LOMO binocular microscope in the Bogorov chamber or in random camera made from Petri dish.

Adults of cyclopids were selected from the samples and transferred with an increase in concentration from 30 to $100 \%$ into pure glycerol, which took about a day. Females were drawn before preparation with a RA-6 drawing apparatus or were photographed using a Levenguk C 800 video camera ( 8 megapixel resolution) for preservation of the general appearance. To identify species they were dissected and mounted on the glass slide according to the method of Prof. F. Kiefer [Kiefer, 1978] — glycerol surrounded by Canada balsam. After dissecting, all taxonomically significant parts of the body were drawn using camera lucida; in some cases, drawings were made from photographs with the obligatory following refinement of details under a microscope. Pencil drawings scanned and improved using Adobe Photoshop and Adobe Illustrator. All permanent slides used in the article are stored in the Federal collection of the Zoological Institute of the Russian Academy of Sciences No. 96-03-16, section Continental Copepoda.

\section{Results}

In total, more than 120 samples were collected and processed in which, along with the well-known species of copepods, 7 new for the fauna of Russia and 2 rarely recorded species of cyclopids from 2 subfamilies and 5 genera of the family Cyclopidae were found, which is about $10 \%$ of the known surface freshwater fauna of cyclopids of Russia, including endemics of Lake Baikal.

\section{Genus Eucyclops Claus, 1893}

\section{Eucyclops (Speratocyclops) dumonti Alekseev, 2000 Fig. 1.}

MORPHOLOGICAL DESCRIPTION. Small crustaceans, females 850-920 $\mu \mathrm{m}$ long (body length without caudal setae). The body is yellowish-brown in color. The first free thoracic somites widened in the posterior part, its width is not less than maximum width of cephalothorax. Fourth thoracic somites with long, strong lateral hairs. The genital double somite somewhat shorter in length than the width, seminal receptacle is bulky, of a typical structure for the genus. The second abdominal somite is almost twice (1.61.8) wider than the third somite following it, but somewhat narrower than the fourth. The anal plate is slightly convex with a smooth outer edge. The caudal branches are very short, diverging; the ratio of their length to width is about three, even less in some individuals.

The innermost caudal seta is rather long, approximately 1.4 times (in some populations even more) longer than spineform outermost seta. Lateral seta short, attached to the last quarter of the length of the outer edge of the ramus or even 

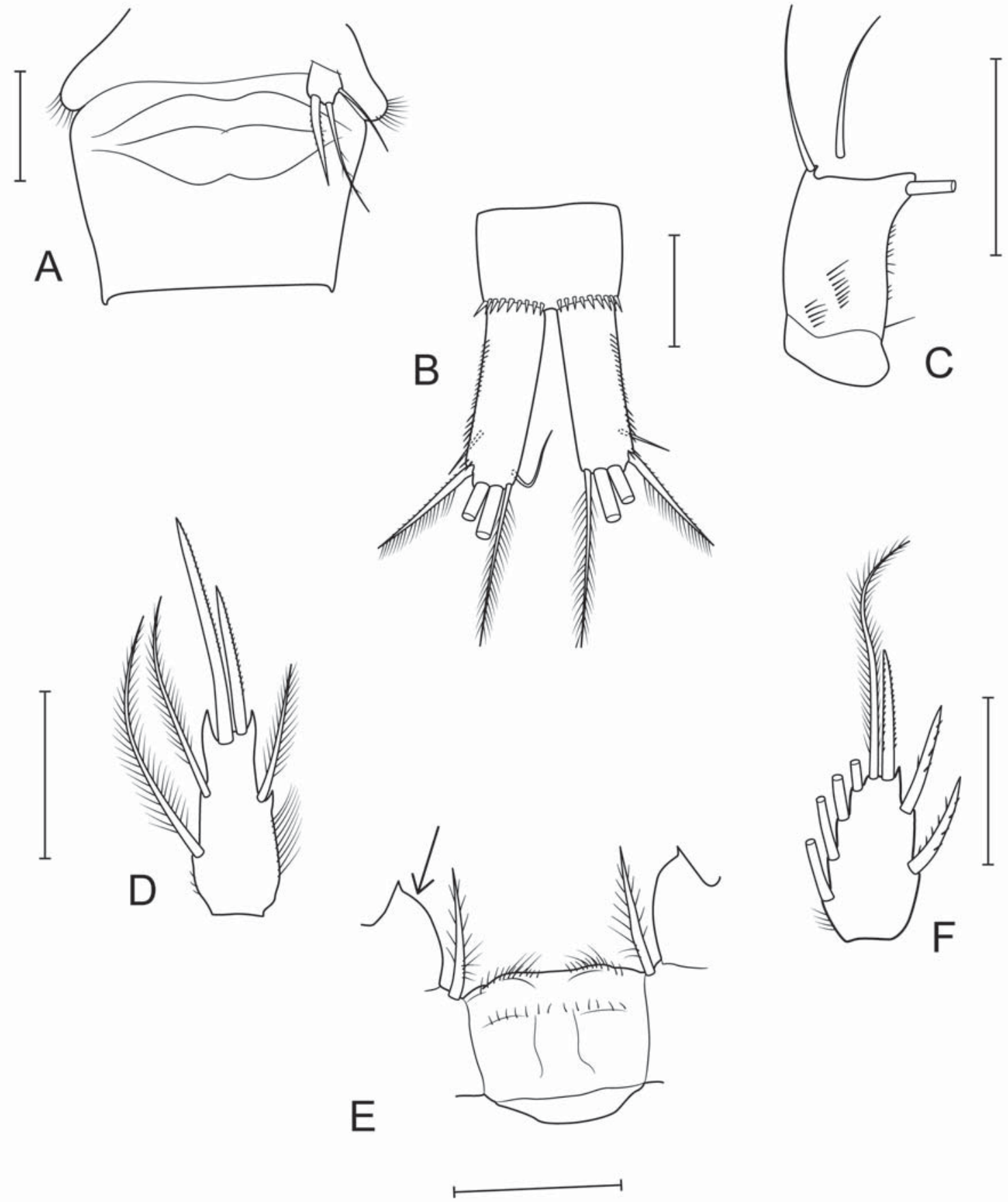

Fig. 1. Eucyclops (Speratocyclops) dumonti Alekseev, 2000, ‥ A — genital double somite and P5; B - caudal rami, ventral; C antenna (A2), caudal; D - P4 endopodite, distal segment; E - P4 intercoxal sclerite; F - P4 exopodite, distal segment. Scale bars: $50 \mu \mathrm{m}$.

Рис. 1. Eucyclops (Speratocyclops) dumonti Alekseev, 2000, ․ А — генитальный сомит и Р5; В — каудальные ветви, вентрально; C — антенна (А2), каудально; D - P4 эндоподит, дистальный сегмент; E — P4 межкоксальная пластинка; F — P4 экзоподит, дистальный сегмент. Масштаб: 50 мкм.

closer to the base of the terminal setae. It is noticeably displaced to the dorsal side. Dorsal seta slightly shorter than outermost seta. Outer margin of caudal rami with lateral serra produced by small denticles proximally and noticeably larger spines distally.

Antennulae 12-segmented, short, slightly projecting beyond the posterior margin of the cephalothorax. Three distal segments on the outer edge with a weakly expressed smooth hyaline membrane. Antennae four-segmented, basipodite caudal surface without long hair-setules at the distal margin (Fig. 1C).

Swimming legs 1-4 (P1-4) two-branched, three-segmented, exopodite spine formula $3 / 4 / 4 / 3$. The distal segment of the endopodite of the fourth pair (P4 Enp3) with 


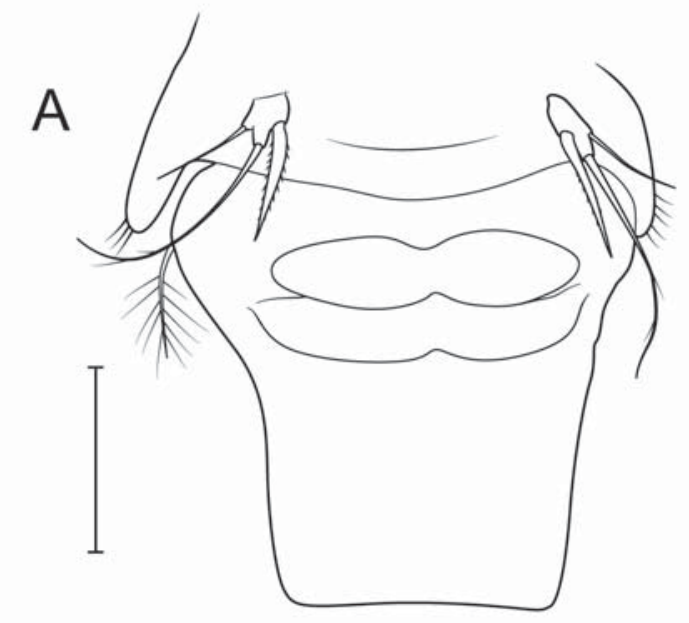

C
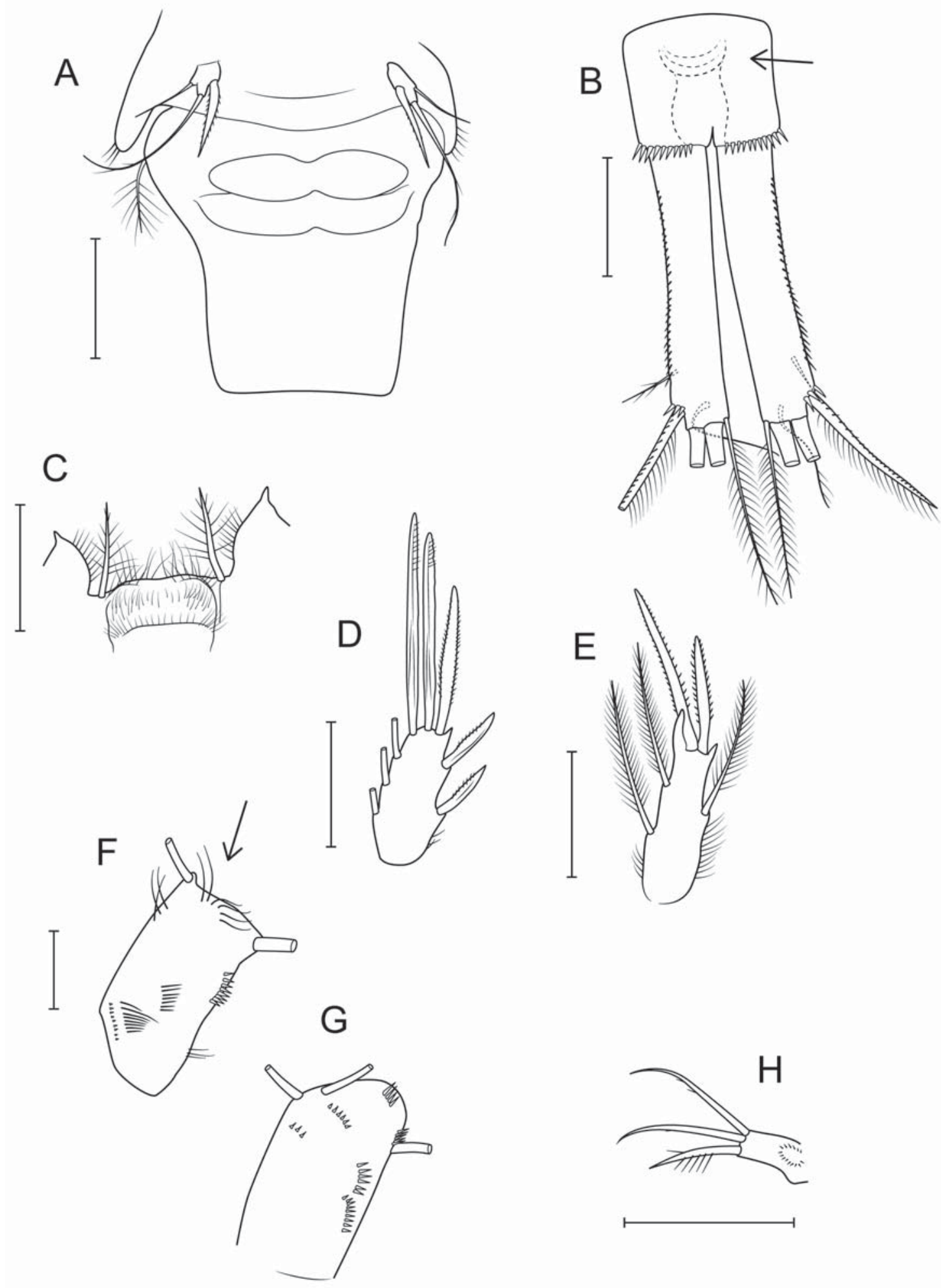

Fig. 2. Eucyclops (Eucyclops) agiloides roseus Ishida, 1997, ․ A — genital double somite and P5; B — caudal rami, ventral; C — P4 intercoxal sclerite; D — P4 exopodite, distal segment; E — P4 endopodite, distal segment; F — antenna (A2), caudal; G — antenna (A2), frontal; $\mathrm{H}$ - maxillular palp. Scale bars: $50 \mu \mathrm{m}$.

Рис. 2. Eucyclops (Eucyclops) agiloides roseus Ishida, 1997, †. А - генитальный сомит и Р5; В - каудальные ветви, вентрально; C - P4 межкоксальная пластинка; D — P4 экзоподит, дистальный сегмент; Е — Р4 эндоподит, дистальный сегмент; F — антенна (А2), каудально; G — антенна (А2), фронтально; Н — пальп максиллулы. Масштаб: 50 мкм. 
two long spines at the end, the inner one is $1.2-1.4$ times as long as outer one. Both spines are straight and strong. Inner spine equal to or longer than the segment itself. The terminal outer seta not reach the middle of the outer spine. Apical spine of exopodite smaller than segment. Inner coxal spine/ seta of P4 plumose on both sides and does not pass beyond the pointed outgrowth of the basipodite. Basipodite outgrowth naked (Fig. 1E, arrow). Intercoxal sclerite with hairs along the outer edge and middle row small spinules.

Fifth reduced leg (P5) in the form of an elongated triangular plate with three appendages: an inner long spine 2 times as long as segment or longer, approximately equal in length to the outer seta; the longest medial seta 1.3-1.5 times as long as the inner spine.

Male. The morphological features of the male basically correspond to those of female, with the exception of a shorter body length and caudal rami.

Important differences from female are the presence of a small number of hairs on inner outgrowth of basipodite of P4. Middle seta of P5 is very long, 2.0-2.5 times as long as the inner spine and the weak outer setae. Rudimentary six leg (P6) represented with short plate not separated from segment armed with long, strong inner spine and two weak subequal outer and middle setae, which are noticeably shorter than spine.

DIFFERENTIAL DIAGNOSIS. The species is quite well distinguished from other Russian representatives of the genus by shortened caudal rami. According to this character, it is closest to E. (S.) arcanus Alekseev, 1990, which was described from the Baikal region and the Bolshezemelskaya tundra, and is apparently widespread in the eastern part of the Palaearctic. E. (S.) dumonti differs from the latter in weakly divergent caudal branches (in $E$. $(S$.) arcanus they are strongly divergent and noticeably curved), as well as in the complete absence of hairs on inner outgrowth of basipodite P4 (in $E$. ( $S$.) arcanus hairs presented).

DATE AND PLACE OF FINDINGS. 1. Vicinity of Baikal, a small shallow pond near Lake Bolshoye Gusinoye, July 2005,5 우

2. River Amur catchment, lakes near the River Zeya, July 2006, 3우, Natalya Sheveleva leg.

DISTRIBUTION. E. (S.) dumonti was described from the Central Mongolia [Alekseev, 2000]. Later it was found in North China. New finding increase this area far to north of Eastern Siberia, but also related with the River Amur catchment and Transbaikalia.

Eucyclops (Eucyclops) agiloides roseus Ishida, 1997 Fig. 2.

MORPHOLOGICAL DESCRIPTION. Female body length without caudal setae $1150-1340 \mu \mathrm{m}$. Forth free thoracic somite with a group of hairs at lateral margin. Anal somite with pronounced, convex anal plate, with double fold (Fig. 2B, arrow). Caudal rami L/W ratio 5.0-5.7, slightly divergent, with lateral serra extending almost to base of ramus, with distal teeth stronger than proximal. Outermost seta spiniform, long and slender, inserted in clear seen distance from other terminal setae, its outer edge with small spinules, inner edge with hairs. Innermost seta 1.1-1.3 times as long as outermost seta. Dorsal seta $0.8-0.9$ times as long as outermost seta. All caudal setae plumose.

Antennule 12-segmented, reaching caudal edge of second free thoracic somite, with smooth (finely serrated) hyaline membrane at three distal last segments. Antenna basi- podite caudal surface with few long hair-like setules distally (position N1,2) (Fig. 2F).

Maxillular (Mxl) palp with a circle formed by small denticles (Fig. 2H).

P1-4 exopodite spine formula 3/4/4/3. P4 intercoxal sclerite with three rows of long hair-setules (I-III). Inner coxal spine/seta homogenously covered with hairs. Distal segment of endopodite P4 2.1-2.7 times as long as wide, with inner spine slightly longer that segment and about 1.5 times as long as outer spine; distal setae reaching only about $1 / 2-2 / 3$ of nearest spine lengths. Distal segment of exopodite P4 with rather long terminal spine slightly longer that segment; distal setae in our specimens spatulate modified (Fig. 2D). P5 with long inner spine almost twice longer than segment and two setae. Setae length ratio beginning with inner spine: $1 / 1.8-2.1 / 0.8-1.1$.

DIFFERENTIAL DIAGNOSIS. The characteristic, distinctive features of E.a. roseus are: smooth hyaline membrane on distal segments of A1; pronounced anal plate, with double fold; A2 basipodite caudal surface with 2 distal groups of hair-setules near medial setae; serra on caudal rami distally formed by strong teeth; very long, dense hairs on intercoxal sclerite free edge of P4; inner coxal spine/seta without "gap" in hairs on lateral side; Mxl palp with round group of small denticles; long and slender (often slightly bend in middle) outermost spine of caudal rami placed on noticeable distance from other terminal caudal setae. From E. (E.) serrulatus (Fischer, 1851) this species can be easily distinguished by the absence of lateral "gap" in hairs on inner coxal spine of P4. From E. (S.) speratus (Lilljeborg, 1901) this species differs primarily by presence of distal hair-setules on A2 basipodite and strong proximal denticles of caudal rami serra. From nominative subspecies $E$. (E.) agiloides agiloides (Sars, 1909) it differs by pronounced anal plate (in E. $(E)$ agiloides it almost straight), presence of long hair-setules distally at medial margin on basipodite A2 (position N2) (in nominative form it's usually missing), presence of circle-like row of small denticles on Mxl palp, presence of hairs on outer edge of first exopodial segments of P2-P4 (in nominative form they are usually missing) [Holynska et al., 2021].

DATE AND PLACE OF FINDINGS: Primorsky Krai:

1. Vladivostok city, Minnye Lakes $\left(44^{\circ} 44^{\prime} 49.9^{\prime \prime} \mathrm{N}\right.$ $\left.132^{\circ} 03^{\prime} 21.4^{\prime \prime} \mathrm{E}\right), 13$ August 2019, 4 우우 (1 with egg sacks).

2. Kamen-Rybolov town vicinity, small river mouth near Khanka Lake $\left(44^{\circ} 44^{\prime} 01.0^{\prime \prime} \mathrm{N} 132^{\circ} 03^{\prime} 23.8^{\prime \prime} \mathrm{E}\right), 14$ August 2019, 2우우.

3. Volchanets town vicinity, small river, $70 \mathrm{~m}$ from confluence into Litovka bay, Gulf Vostok $\left(42^{\circ} 54^{\prime} 38.9^{\prime \prime} \mathrm{N}\right.$ $\left.132^{\circ} 45^{\prime} 36.5^{\prime \prime} \mathrm{E}\right), 19$ August 2019, 4웅.

DISTRIBUTION. Asia, Africa, Europe (? possibly invasive). New findings indicate that the species is widespread in the Primorsky Krai, where it is often found together with E. speratus.

\section{Eucyclops (Denticyclops) euacanthus (Sars, 1909)} Fig. 3.

MORPHOLOGICAL DESCRIPTION. Female body length without caudal setae less than $1 \mathrm{~mm}(850-950 \mu \mathrm{m})$, painted in light brown tones. The lateral parts of the fourth free thoracic somite with a group of long, strong hairs. Caudal rami widely spaced, slightly curved, diverging. The innermost seta is thin and straight, nude or with sparse hairs, it is at least one and a half, and sometimes twice as long as the outermost spine, but two or even three times thinner than 


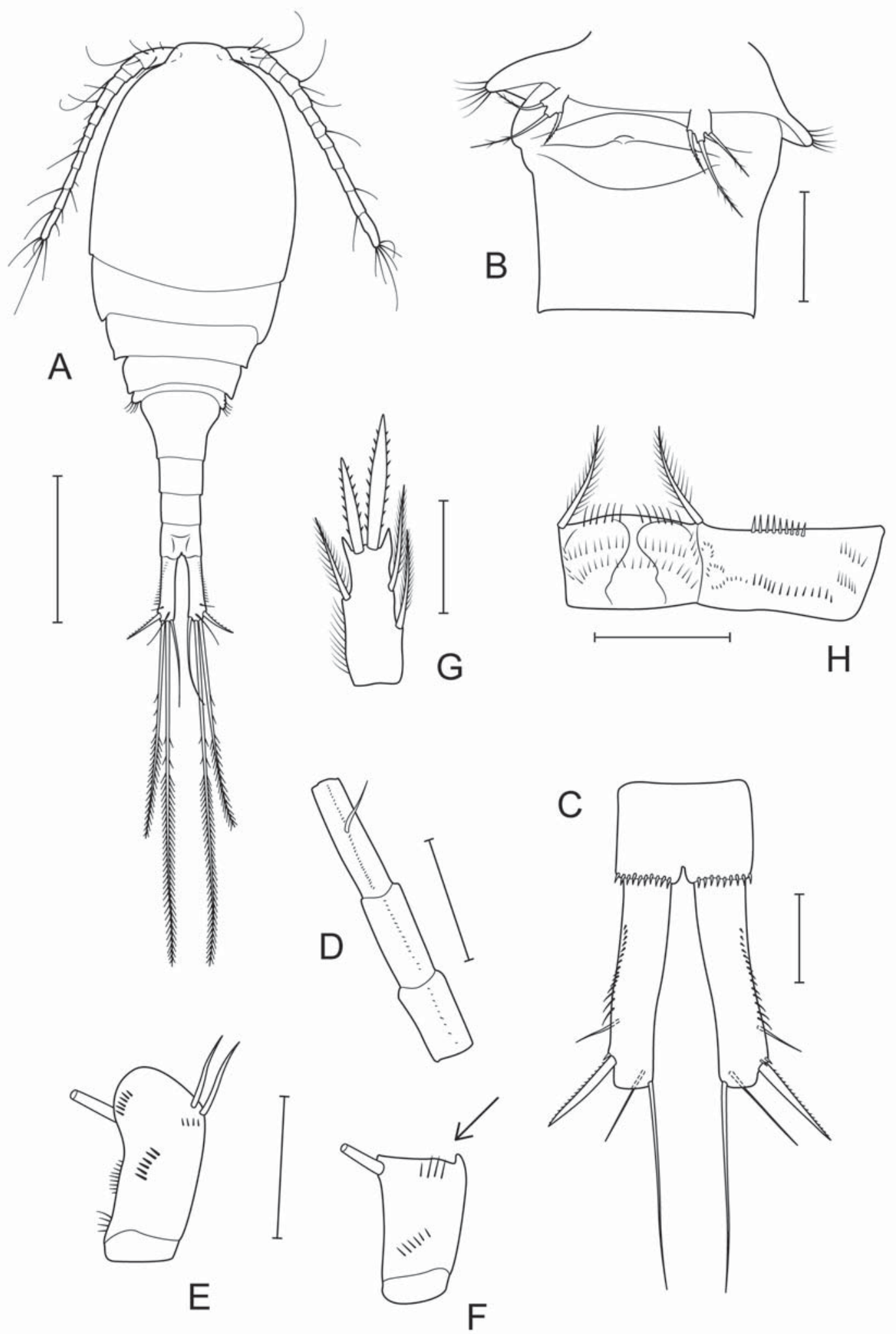

Fig. 3. Eucyclops (Denticyclops) euacanthus (Sars, 1909), ‥ A - habitus; B — genital double somite and P5; C - caudal rami, ventral; D - antennule (A1), distal segments; E - antenna (A2), frontal; F — antenna (A2), caudal; G — P4 endopodite, distal segment; $\mathrm{H}-\mathrm{P} 4$ intercoxal sclerite. Scale bars: A $-200 \mu \mathrm{m}, \mathrm{B}-\mathrm{H}-50 \mu \mathrm{m}$.

Рис. 3. Eucyclops (Denticyclops) euacanthus (Sars, 1909), ‥ А - общий вид; В - генитальный сомит и Р5; С - каудальные ветви, вентрально; D - антеннула (А1), дистальные сегменты; Е — антенна (А2), фронтально; F — антенна (А2), каудально; G P4 эндоподит, дистальный сегмент; Н - P4 межкоксальная пластинка. Масштаб: А -200 мкм, В-H - 50 мкм. 
the latter. The middle setae of the caudal ramus are thin and straight. Dorsal seta weak and approximately equal in length to outermost spine. From the place of attachment of the lateral seta, which is clearly displaced to the dorsal surface of the branches, a row of long spines rises up the caudal ramus (proximally significantly decreasing) - serra, which clearly does not reach the proximal base of ramus.

Antennule 12-segmented, reaching caudal edge of cephalothorax, with tiny denticles at three distal segments. Antenna caudal surface with a group of setules at the distal margin (Fig. 3F, arrow).

P1-4 exopodite spine formula 3/4/4/3. Exopodites with strong, wide spines with large denticles. The distal segment of the P4 endopodite (length to width ratio 2.4 ) with two long knife-like spines, the inner one is 1.2-1.4 times as long as outer one and subequal to segment; distal setae reach only middle of nearest spines. P4 coxal spines homogenously plumose, reaching tips of basipodite outgrowths. Intercoxal sclerite distal edge with short stiff spinules and two middle rows of setules.

P5 with short, thin inner spine and two longer setae.

DIFFERENTIAL DIAGNOSIS. It differs well from closely related species of the genus in appearance of the caudal rami: the outermost spine located far from the end of the rami and located on a distinct protrusion; innermost seta thin and almost nude. The structure of the fifth pair of legs with a thin weak spine and longer setae is very characteristic of the species.

DATE AND PLACE OF FINDINGS: South of Kamchatka, noname lake near Kurilskaya hill, sample of littoral zooplankton, collected by Prof. Henri Dumont, July 2004.

DISTRIBUTION. E. euacanthus was described [Sars, 1909] from the lakes of the Rift Valley of Equatorial Africa (Lake Tanganyika). Later it was repeatedly found in various countries of Southeast Asia and Australia [Dussart, Defaye, 2006]. The closest location is the islands of Japan. The finding of this species in Kamchatka, apparently, marks the most northern part of its modern range, which covers the tropics and subtropics of the Old World, including Australia.

\section{Genus Ectocyclops Brady, 1904}

\section{Ectocyclops polyspinosus Harada, 1931} Fig. 4.

MORPHOLOGICAL DESCRIPTION. Females body length (measured as sum of telescoping segment lengths) $1020-1350 \mu \mathrm{m}$, almost black when alive, and dark brown when fixed with formalin. The body is strongly flattened in the dorsoventral direction. Maximum width closer to the caudal end of the cephalothorax. All subsequent somites are narrower than the previous ones, so that the anterior part (prosoma) is presented as an almost regular extended oval. Fourth free thoracic somite laterally with strong setules. Genital somite rather short, with width about 1.1-1.2 times as long as length. Anal somite posteriorly with dense row of flat spinules, dorsally short, ventrally very long. Anal plate weakly developed, with long spinules at sides. Caudal rami are short, 1.8-2.4 as long as wide, spaced less than half the width of the branch at its base. Anterior part of dorsal surface of caudal rami bears about 3 oblique rows of small stiff hair-setules. Posterior part of dorsal surface with nonorganized in rows field of smaller setules. Ventral surface bear posterior row of flat long spinules (from shorter lateral ones, covering the outermost seta, to longer ventral ones).
Another few flat long spinules placed at site of insertion of lateral seta. Innermost seta with short hairs distally and few denticles proximally, it is weak and short, about as long as outermost seta. Outermost seta strong, plumose on both sides. Dorsal seta clearly longer that outermost seta. Two middle caudal setae strong and straight, inner one about 2.5 times as long as outer one, and heteronomously plumose: partly with hairs, partly with strong spinules (mostly outer side).

Antennule (A1) 11-segmented, very short, not reaching the distal border of cephalothorax. First segment with semicircle of spinules. Aesthetasc on $10^{\text {th }}$ segment long, reaching and exceeding beyond place of insertion of medial seta of $11^{\text {th }}$ segment. Antenna (A2) four-segmented: basipodite and 3 endopodite segments. A2 basipodite with 2 medial setae and long and thick exopodial rudimentary seta, ornamentation of caudal surface shown in Fig. 4E. Exp seta with long spinules along medial side, at proximal part directed perpendicular to seta, and short rarely placed spinules along lateral side. A2 Enp1 with 1 short and thick seta/spine bearing long stiff spinules, the segment itself bears dense longitudinal field of long stiff spinules across caudal side, row of long stiff spinules at medial margin, and few shorter spinules at lateral margin. A2 Enp2 with 9 setae, one of which modified in short spine with stiff spinules as on Enp1. A2 Enp2 with 7 setae.

Swimming legs 1-4 three-segmented, with spine formula $3 / 4 / 4 / 3$. Outer sides of segments bear long flat spinules sometimes combined with hairs. P4 intercoxal sclerite long and narrow, with middle row of tiny denticles and with two large humps emerging beyond free margin; these humps bear group of hair-setules on one side and curved thick seta on another side. Coxopodal seta short, weak and bare, only slightly exceeds beyond basipodite outgrowth. Inner basipodite outgrowth distally bears a group of dense hairs on one side and semicircular row of spinules on another. P4 coxopodite bears a long distal row of strong flat spinules, dense hairs laterally and few spinules medially. P4 Enp3 segment short, oval form, with $\mathrm{L} / \mathrm{W}$ ratio about 1.5 ; of two apical spines the inner one twice as long as outer one; inner spine with strong denticles, outer spine with tiny denticles; outer side of segment bears long hairs proximally and flat spinules distally, inner side with few hairs.

Reduced P5 in the form of a weakly detached wide plate with three appendages of almost equal length: two spines and a slightly thinner seta (Fig. 4B).

Male P6 represented by a strong long inner spine and two thin setae, of which the outer one is 0.5 times as long as the spine, the middle one is 0.7 times as long as the inner spine.

DIFFERENTIAL DIAGNOSIS. This species can be distinguished from E. phaleratus (Koch, 1838), the common European representative of Ectocyclops in Russia, by its 11segmented antennule (A1 of E. phaleratus is 10-segmented).

DATE AND PLACE OF FINDINGS: 1. Irkutsk, small grassy bay of the Verkhne-Angarsk reservoir, August, 2012, 3 우오.

2. Primorsky Krai, Russkiy Island, Lake Akhlestysheva $\left(42^{\circ} 59^{\prime} 37.8^{\prime \prime} \mathrm{N} 131^{\circ} 55^{\prime} 54.4^{\prime \prime} \mathrm{E}\right)$, depth $\sim 40 \mathrm{~cm}$, among vegetation, with a hand net, 13 August 2019. The sample contained 2 \% $\left(1\right.$ with egg sacks) and $10^{7}$ of E.polyspinosus together with Mesocyclops leuckarti (Claus, 1857) and Eucyclops speratus.

3. Irkutsk, Leninsky district, pond $\left(52^{\circ} 18^{\prime} 19.3^{\prime \prime} \mathrm{N} 104^{\circ} 15^{\prime}\right.$ $20.8^{\prime \prime} \mathrm{E}$ ), the sample collected by $8-\mathrm{m}$ net throw, $1 \mathrm{~m}$ depth, among elodea, 10 July 2021. The sample contained 2 \% 9 of 

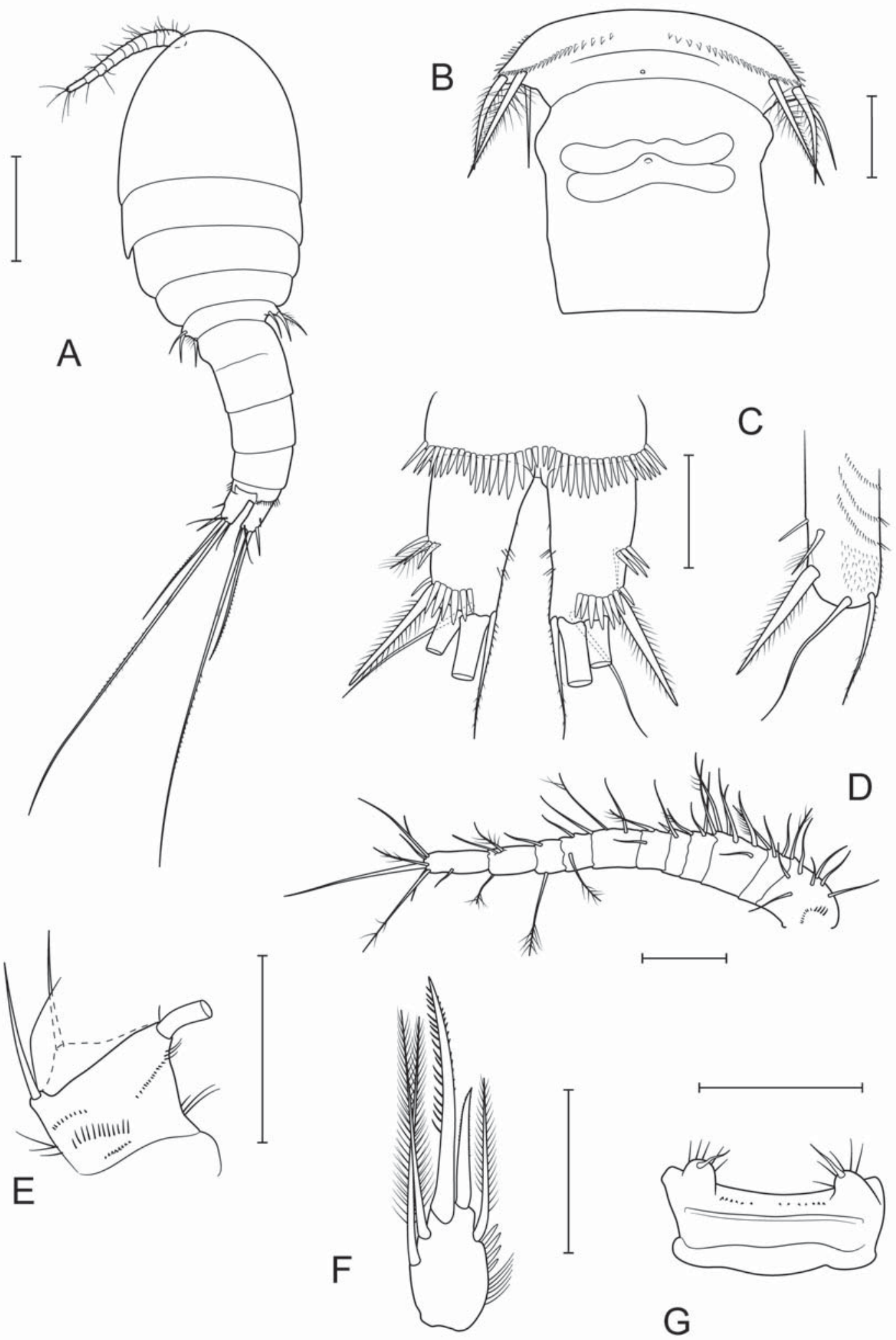

Fig. 4. Ectocyclops polyspinosus Harada, 1931, + . A — habitus, dorsal; B — genital double somite and P5; C — caudal rami, ventral and dorsal; D - antennule (A1); E — antenna (A2), caudal; F — P4 endopodite, distal segment; G — P4 intercoxal sclerite. Scale bars: $\mathrm{A}-200 \mu \mathrm{m}, \mathrm{B}-\mathrm{G}-50 \mu \mathrm{m}$.

Рис. 4. Ectocyclops polyspinosus Harada, 1931, ๆ. А - общий вид, дорсально; В - генитальный сомит и Р5; С — каудальные ветви, вентрально и дорсально; D — антеннула (A1); Е — антенна (A2), каудально; F — Р4 эндоподит, дистальный сегмент; G — P4 межкоксальная пластинка. Масштаб: $\mathrm{A}-200$ мкм, B-G - 50 мкм. 
E. polyspinosus as well as some fish fry, 11 Mesocyclops leuckarti, 4 Eucyclops denticulatus (Graeter, 1903), and 1 Cryptocyclops bicolor bicolor (G.O. Sars, 1863).

DISTRIBUTION. The type habitat of E. polyspinosus is the island of Taiwan [Harada, 1931], but the species is widespread in Southeast Asia, where it reaches almost the equator. VA found it in Singapore, Malaysia, Thailand, South and North Vietnam, South China (Guangzhou region and Hainan Island), Taiwan.

\section{Genus Cyclops O.F. Müller, 1785}

$$
\begin{gathered}
\text { Cyclops borealis Lindberg, } 1956 \\
\text { (= C. heberti Einsle, 1996) } \\
\text { Figs 5, } 6 .
\end{gathered}
$$

MORPHOLOGICAL DESCRIPTION. Female body length (measured as sum of telescoping segments lengths) without caudal setae 1351-1645 $\mu \mathrm{m}$ (in 4우). First free thoracic somite without developed posterolateral lobes. Third free thoracic somite posterior angles not prolonged (without "wings"). Th4 lateral angles pointed outwards, blunt. Caudal rami L/W ratio 5.1-5.5, divergent, with dorsal crest. Inner margin covered with hairs, anterior group pointed proximally or perpendicular to margin. Lateral seta inserted at about $1 / 4$ of ramus length distally. Small spinules present at places of insertion of lateral and outermost setae. Innermost caudal seta $0.65-0.88$ as long as ramus length, and 1.211.57 as long as outermost seta. Dorsal seta clearly shorter than outermost seta. All caudal setae plumose.

Antennule (A1) 17-segmented, covered with pits dorsally (numerous on $1-4^{\text {th }}$ segments), reaching middle or $2 / 3$ of first free thoracic somite. Three distal segments with clearly seen dense teeth. Aesthetasc on segment 12 reaching middle of segment 14, aesthetasc on segment 16 reaching (or almost reaching) medial seta of $17^{\text {th }}$ segment.

Antenna (A2) setation: 3, 1, 9, 7. Medial setae of basipodite without long hairs. Frontal ornamentation shown on Fig. $6 \mathrm{H}$.

Maxillular palp with few proximal long hairs on two proximal setae (Fig. 6D). Maxilliped with syncoxopodite covered with tiny spinules (Fig. 6C).

Swimming legs spine formula $3 / 4 / 3 / 3$ ("Terni" type). P1 basipodite seta reaching beyond posterior margin of second endopodite, with homogenous short setules (Fig. 5C). Long spinules present on protuberance between exo- and endopodites.

P4 intercoxal sclerite with two rows of hairs (in some specimen poorly visible). Two small humps always emerging beyond free margin (more or less, depending on degree of straightening of sclerite). Coxopodite ornamentation variation shown on Fig. 5E, F (in one specimen two small spines present at distal border (group D) in addition). In row of distal spines (group C) first 1-2 especially large and thick. P4 Enp3 L/W about 2.4, inner spine about as long as segment, and about twice of outer spine length.

P5 with rather short lateral seta of first segment, rather long apical seta and strong medial spine inserted at middle of second segment (Fig. 6B).

DIFFERENTIAL DIAGNOSIS. C. borealis most resembles in appearance and proportions and therefore can be confused with $C$. strenuus (Fischer, 1851), C. abyssorum G.O. Sars, 1863, C. divergens Lindberg, 1936, C. furcifer Claus, 1857 or C. sibiricus Lindberg, 1949 (=C. canadensis Einsle, 1988). However, humps on intercoxal sclerite of P4 are very low in $C$. strenuus and do not protrude beyond free margin, while in $C$. borealis they always protrude. C. borealis can be distinguished from $C$. abyssorum and $C$. divergens, in which humps of $\mathrm{P} 4$ also noticeably protrude, by weaker and shorter hairs on its intercoxal sclerite, as well as by weaker lateral projections on $\mathrm{Th} 4$, as in these species they are stronger, triangular formed. C. sibiricus can be distinguished by characteristic downwardly protruding lateral projections on $\mathrm{Th} 4$, directed along the abdomen; and short coxal spine in P4 not reaching beyond basipodite outgrowth. In C. furcifer, genital somite is significantly enlarged proximally, and then sharply narrows in the middle, while in C. borealis, the narrowing of genital somite is much more gradual.

When in doubt, microcharacters can help [Holynska, Dahms, 2004]. For example, the seta of $P 1$ basipodite in $C$. abyssorum and $C$. divergens usually covered with longer setules. The maxilliped syncoxopodite, in contrast to $C$. borealis, in all compared species (except $C$. divergens) bears a distal group of large spines (though in $C$. abyssorum they can be small sometimes). The presence of long hairs on first (proximal) two setae of maxillular palp distinguishes $C$. borealis from $C$. strenuus and C. sibiricus, which have only short hairs on maxillular palp setae. $C$. furcifer has long hairs, but they cover the entire length of setae, while in $C$. borealis only the proximal part. C. abyssorum and C. divergens bear long hairs only on the first (proximal) seta. Besides, in $C$. divergens maxillular palp bear transverse row of large spinules proximally (very rarely absent) while in $C$. borealis maxillular palp has only tiny scattered spinules. At the same time, the variability of these microcharacters in different populations has not been sufficiently studied, therefore, they should be used with an appropriate degree of caution.

DATE AND PLACE OF FINDINGS: Irkutsk, Konny Island, near the railway bridge in a roadside ditch, among vegetation $\left(52^{\circ} 15^{\prime} 56.5^{\prime \prime} \mathrm{N} 104^{\circ} 16^{\prime} 42.7^{\prime \prime} \mathrm{E}\right)$, collected by hand net, 5 July 2021. The sample contained 4 우 of C.borealis together with 11 우 of Acanthocyclops vernalis (Fischer, 1853).

DISTRIBUTION. Described from Sweden [Lindberg, 1956] and later as " $C$. heberti" from Germany [Einsle, 1996] C. borealis was reported also from France, Poland, Italy, Mongolia, Uzbekistan [Holynska, Wyngaard, 2019]. It was found by us in small numbers near Baikal Lake. Its close resemblance to a number of other cyclops may "obscure" its presence in other regions.

COMMENTS. C. borealis in its native habitat falls into summer diapause in March-April, from which it emerges in autumn in the stage of fourth copepodids [Einsle, 1996]. Only a small part of the population produces a new generation in May, which are significantly inferior in body size to winter specimens (which reach and exceed $2 \mathrm{~mm}$ ). Several females found by us are apparently few remaining representatives of the last generation. They are similar in body size to the May samples from Germany, the average length of which was $1540 \mu \mathrm{m}$ [Einsle, 1996].

\section{Genus Megacyclops Kiefer, 1927}

Megacyclops magnus (Marsh, 1920)

Fig. 7.

MORPHOLOGICAL DESCRIPTION. Female body length without caudal setae about $1 \mathrm{~mm}$. Caudal rami L/W 

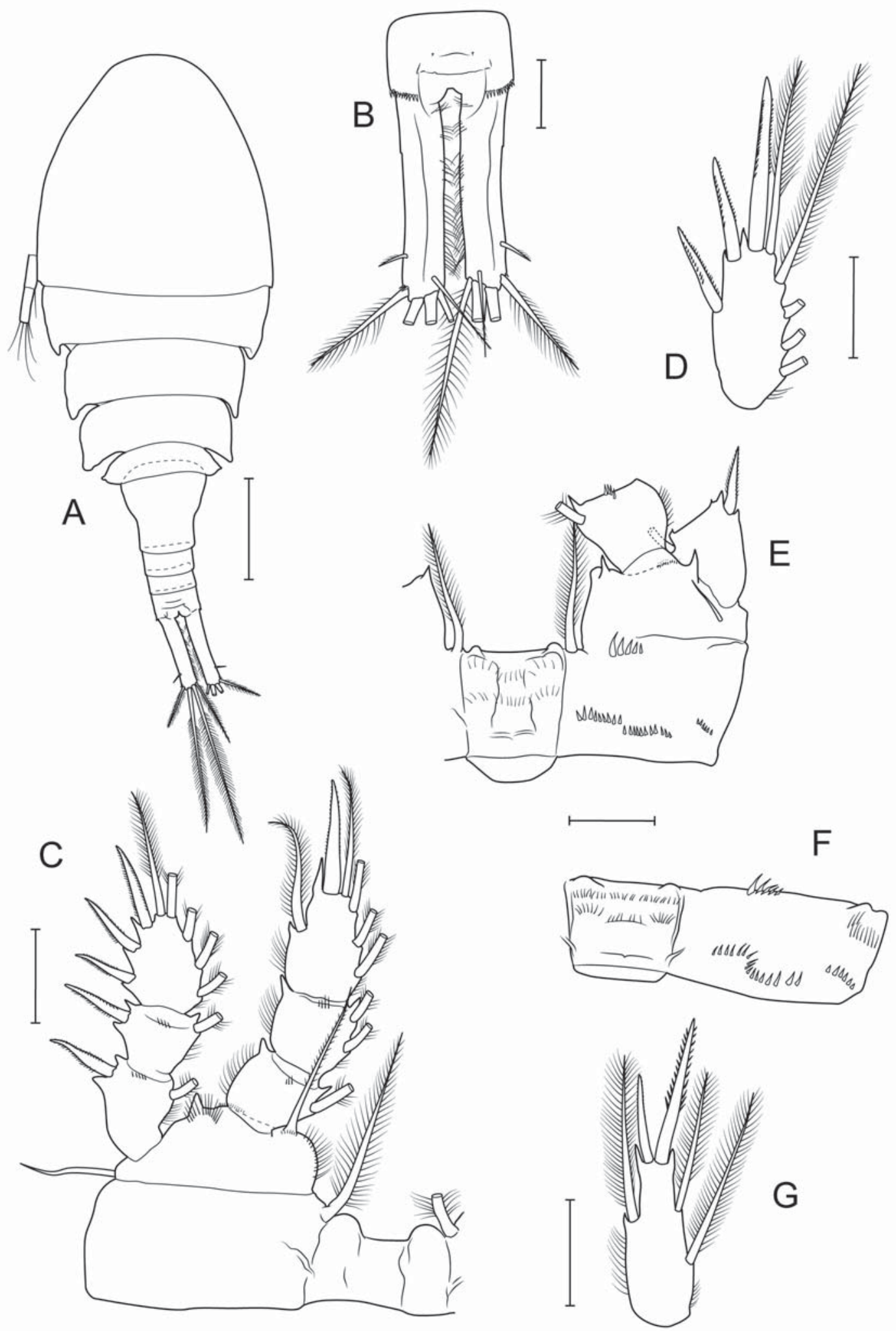

Fig. 5. Cyclops borealis Lindberg, 1956, ․ A - habitus, dorsal; B — caudal rami, dorsal; C — P1; D — P4 exopodite, distal segment; E - P4 intercoxal sclerite and coxopodite; F - P4 intercoxal sclerite and coxopodite, variation; G - P4 endopodite, distal segment. Scale bars: A $-200 \mu \mathrm{m}, \mathrm{B}-\mathrm{G}-50 \mu \mathrm{m}$.

Pис. 5. Cyclops borealis Lindberg, 1956, ․ А — общий вид, дорсально; В - каудальные ветви, дорсально; С - P1; D - P4 экзоподит, дистальный сегмент; E - P4 межкоксальная пластинка и коксоподит; F - Р4 межкоксальная пластинка и коксоподит, вариант; G - P4 эндоподит, дистальный сегмент. Масштаб: A - 200 мкм, B-G - 50 мкм. 

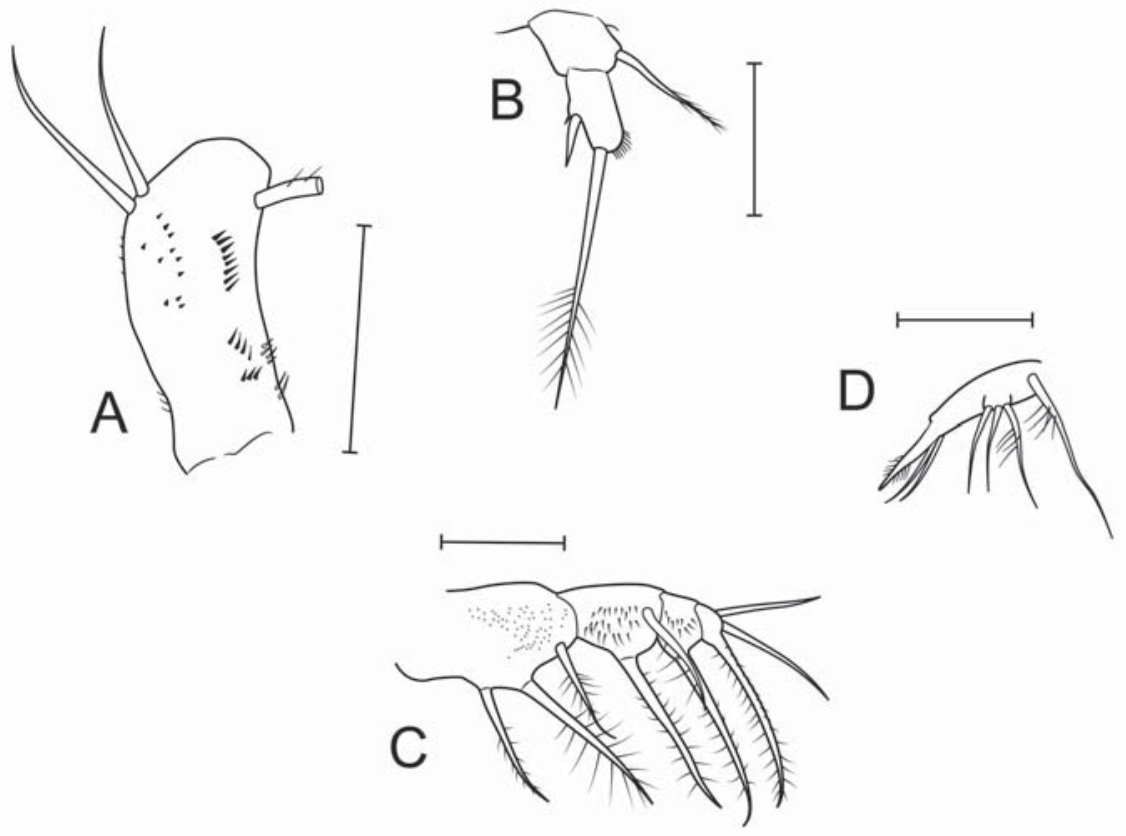
$\mu \mathrm{m}$.

Fig. 6. Cyclops borealis Lindberg, 1956, + . A — antenna (A2), frontal; B — P5; C - maxilliped; D - maxillular palp. Scale bars: 50

Рис. 6. Cyclops borealis Lindberg, 1956, ․ А — антенна (А2), фронтально; В — P5; С — максиллипед; D — пальп максиллулы. Масштаб: 50 мкм.

ratio 3.6, almost parallel, inner margins covered with short dense hairs. Dorsal seta 0.8 times as long as outermost seta. Innermost seta rather short, slightly shorter than caudal ramus and 1.5 times as long as outermost seta.

Antennule (A1) 17-segmented, almost reaching posterior edge of cephalothorax. Antenna (A2) second endopodite segment with 9 setae, ornamentation of basipodite shown in Fig. 7B, C.

Swimming legs spine formula $2 / 3 / 3 / 3$. P4 intercoxal sclerite with middle row of strong denticles. P4 coxopodite with proximal and distal rows of strong denticles and lateral groups of hair-setules. P4 Enp3 short, with L/W ratio 1.6. Two apical spines shorter than segment, inner spine noticeably shorter than outer spine, and distal setae almost reaching tips of adjacent spines.

P5 with wide proximal segment and narrow distal segment; lateral seta almost equal to apical seta; inner spine tiny.

DIFFERENTIAL DIAGNOSIS. $M$. magnus differs from other congeners by inner/outer spines lengths ratio in P4 which is less than 1, i.e. inner spine of P4 shorter than outer spine. Besides, M. viridis (Jurine, 1820) has significantly longer innermost seta which is 1.3-1.9 times as long as caudal ramus length while in M. magnus it is almost equal to ramus length. Hairs on inner surface of caudal rami present proximally not only on inner edge but on dorsal surface almost to the middle of it, while in $M$. viridis and $M$. gigas (Claus, 1857) hairs are located only along the inner surface [Einsle, 1993]. In M. latipes (Lowndes, 1927) distal setae of P4 Enp3 extending beyond ends of nearest spines, while in M. magnus these setae are shorter.

DATE AND PLACE OF FINDINGS: Primorsky Krai, Kamen-Rybolov town, shallow stream of muddy water, at depth $\sim 30 \mathrm{~cm}, 400 \mathrm{~m}$ from shore of Lake Khanka $\left(44^{\circ} 44^{\prime}\right.$
03.3"N $\left.132^{\circ} 03^{\prime} 02.4^{\prime \prime} \mathrm{E}\right), 15$ August 2019. The sample contained 2 ㅇ․

DISTRIBUTION. M. magnus was described [Marsh, 1920] from specimens collected on Chantry Island (Bernard Harbor), Canada in June 17, 1916 [Yeatman, 1944]. The name "Cyclops magnus" was given due to the large size of these specimens $(1.85-2.4 \mathrm{~mm})$. This species has a characteristic difference from other representatives of the genus a different ratio of the lengths of the apical spines of the P4 endopodite. Another notable difference from close M. viri$d i s$ is the short innermost seta, which is shorter or slightly longer than caudal ramus length, while in $M$. viridis it is significantly longer.

Later, Ishida [Ishida, 2002] found Megacyclops with a similar ratio of these spines in Japan, presumably referring them to Megacyclops magnus on this basis. Following him, South Korean authors described the finds of similar specimens in South Korea [Lee et al., 2007]. At the same time, specimens found in Japan, South Korea and the Far East of Russia differ from North American ones noticeably in their small size $(0.9-1.1 \mathrm{~mm})$.

Genus Mesocyclops G.O. Sars, 1914

Subgenus Mesocyclops (Pilosomesocyclops) Alekseev, 2020

Mesocyclops (Pilosomesocyclops) mariae Guo, 2000 Fig. 8.

MORPHOLOGICAL DESCRIPTION. Female body length without caudal setae $1000-1050 \mu \mathrm{m}$ (in 2 우). Forth free thoracic somite (Th4) with short hairs anterio-laterally. Receptaculum seminis with wide and long lateral arms, prox- 

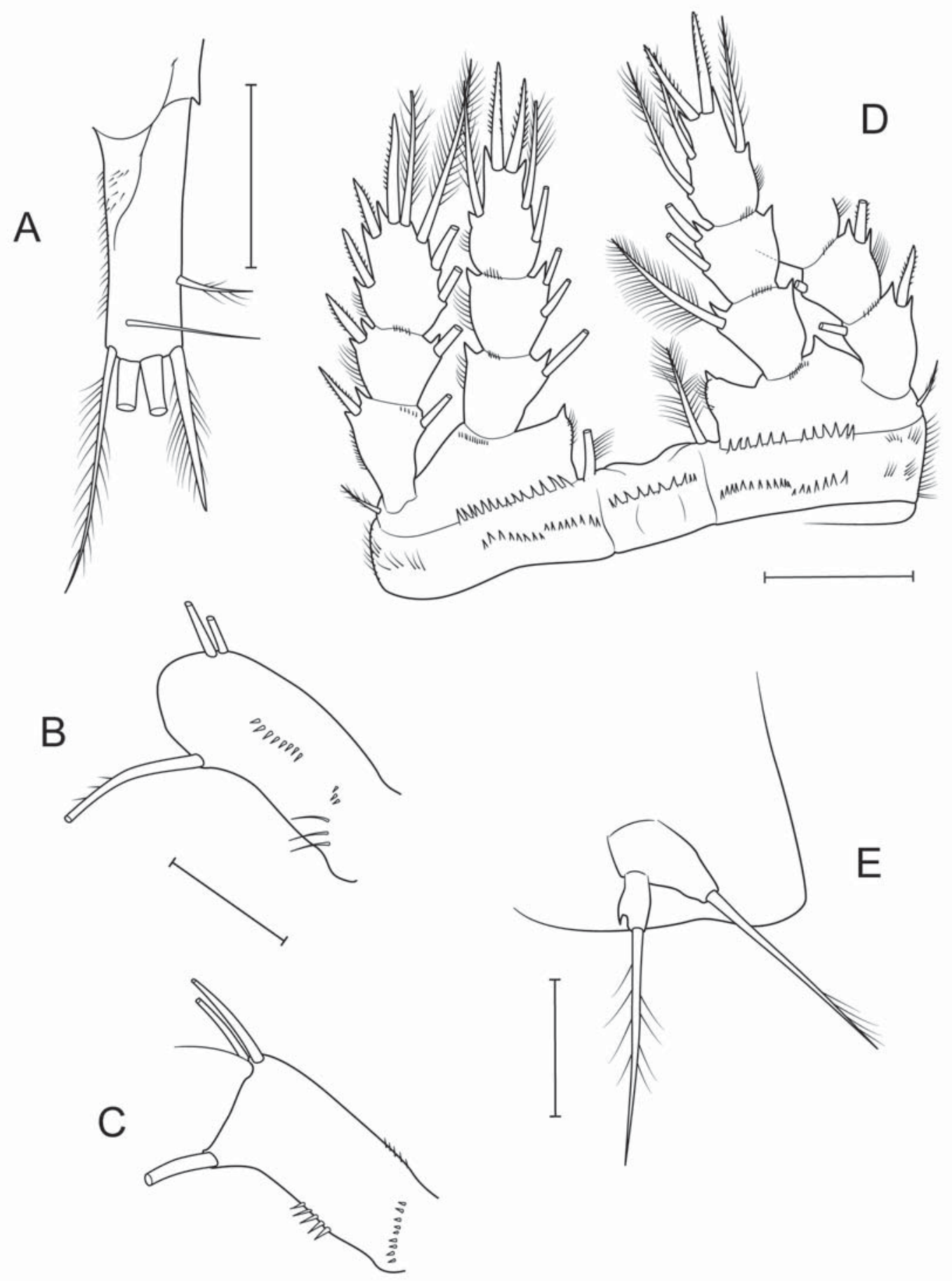

Fig. 7. Megacyclops magnus (Marsh, 1920), 9 . A — caudal ramus, dorsal; B — antenna (A2), frontal; C — antenna (A2), caudal; D P4; E - P5. Scale bars: A - $100 \mu \mathrm{m}$; B, C $-50 \mu \mathrm{m}$; D $-100 \mu \mathrm{m}$; E $-60 \mu \mathrm{m}$.

Pис. 7. Megacyclops magnus (Marsh, 1920), ․ А — каудальная ветвь, дорсально; В - антенна (А2), фронтально; С - антенна (А2), каудально; D — P4; E — P5. Масштаб: А — 100 мкм; В, С — 50 мкм; D - 100 мкм; Е — 60 мкм.

imal part sinuate in middle, transverse ducts meeting at straight angle, copulatory duct wide and straight (but with dorsoventral curvature). Caudal $\mathrm{rami} \mathrm{L} / \mathrm{W}$ ratio $3.5-3.7$, slightly divergent. Proximal half of inner margin bears hairs packed in groups. All caudal setae plumose. Lateral seta longer than ramus length. No spinules at places of insertion of lateral and outermost setae. Dorsal seta 0.8 times as long as outermost seta. Innermost seta $2.5-2.8$ times as long as outermost seta and twice as long as ramus length. Relative lengths of caudal setae beginning with outermost: $1.0 / 4.5-$ $5.2 / 6.7-7.5 / 2.5-2.8$.

Antennule (A1) 17-segmented, last two segments bear wide hyaline membrane with one notch. Antenna (A2) second endopodite segment with 7 setae, ornamentation of ba- 
B

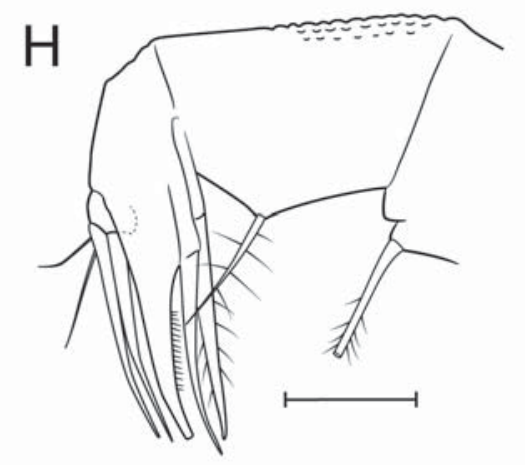

$\mathrm{F}$
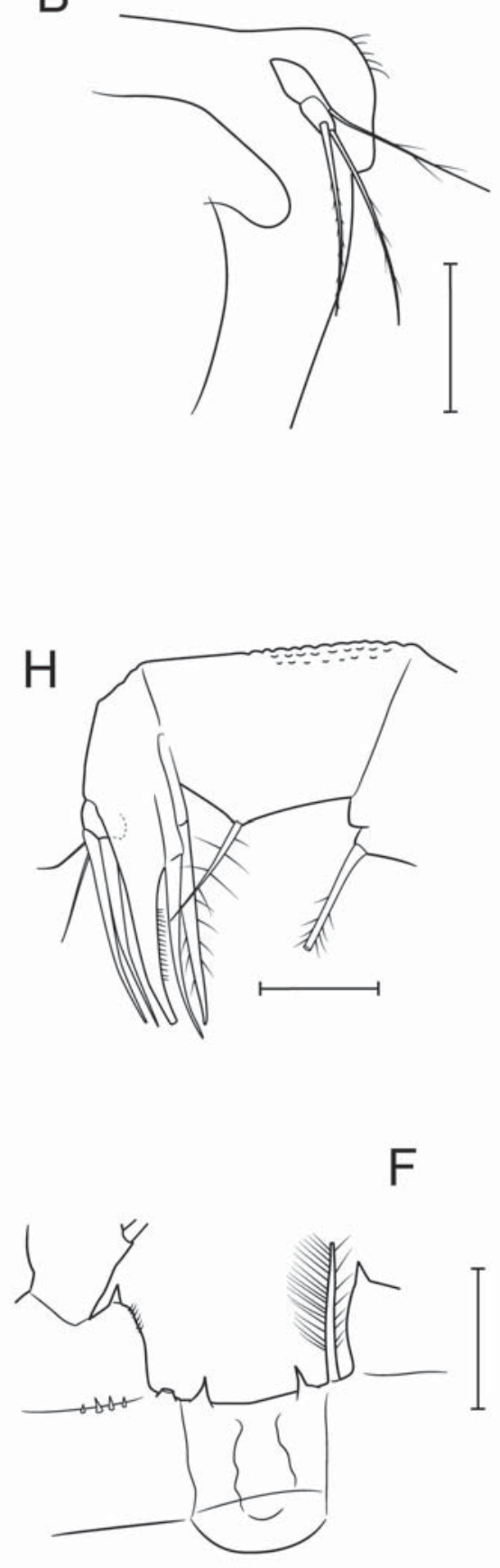

A

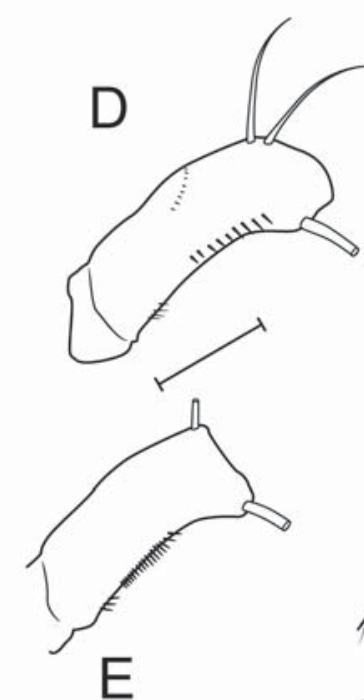

$\mathrm{E}$

$\mathrm{C}$

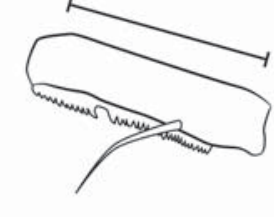

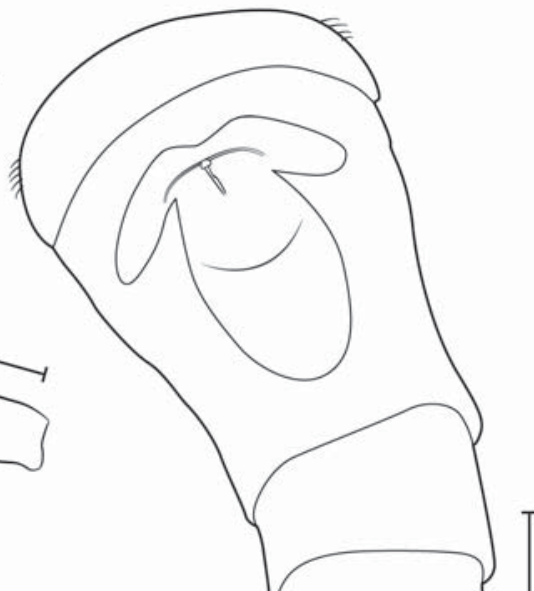
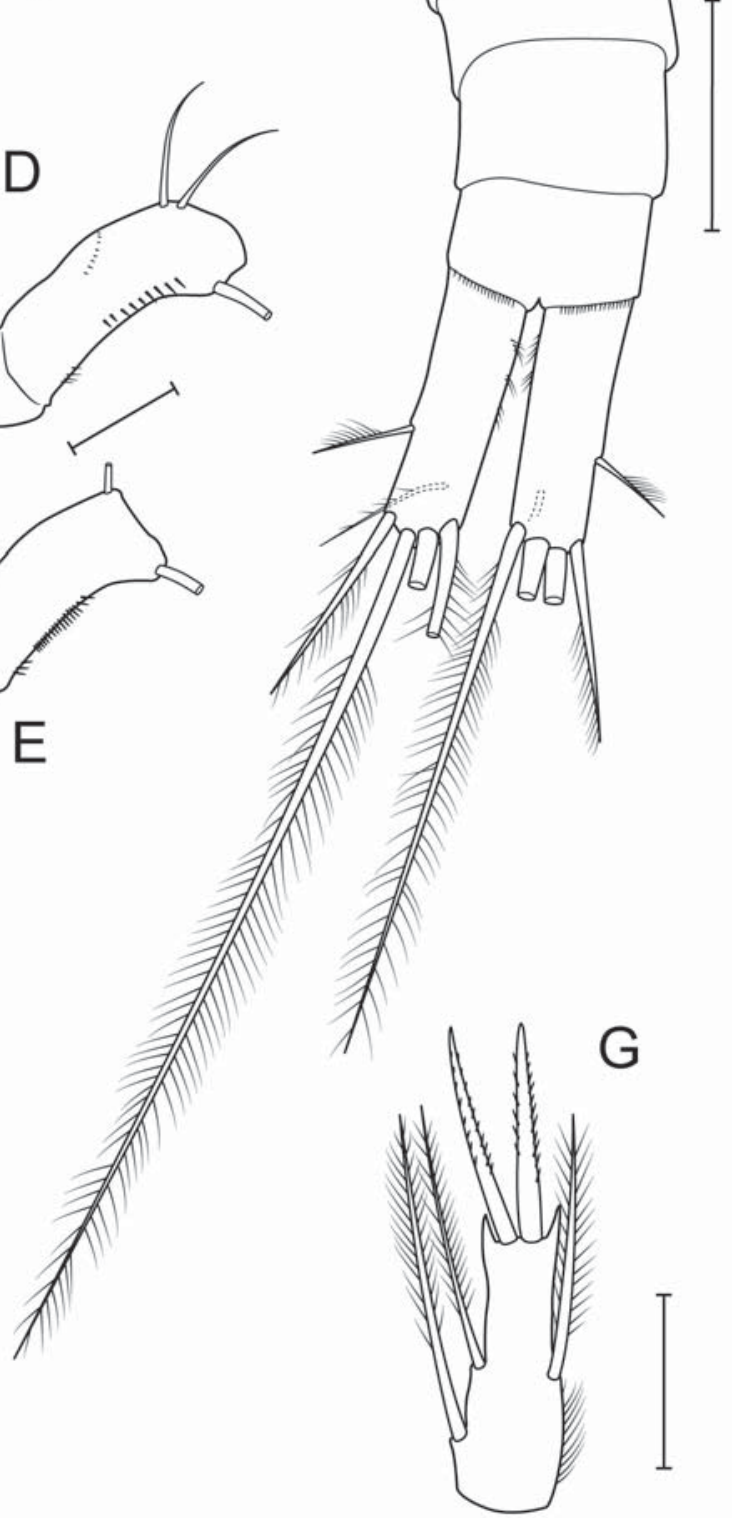

Fig. 8. Mesocyclops (Pilosomesocyclops) mariae Guo, 2000, ․ A - abdomen, ventral; B - P5; C — antennule (A1), distal segment; D - antenna (A2), frontal; E - antenna (A2), caudal; F — P4 intercoxal sclerite; G - P4 endopodite, distal segment; H maxilla. Scale bars: A $-100 \mu \mathrm{m} ; \mathrm{B}-\mathrm{H}-50 \mu \mathrm{m}$.

Рис. 8. Mesocyclops (Pilosomesocyclops) mariae Guo, 2000, ․ А - абдомен, вентрально; В - P5; С - антеннула (A1), дистальный сегмент; D - антенна (А2), фронтально; Е — антенна (А2), каудально; F — P4 межкоксальная пластинка; G — P4 эндоподит, дистальный сегмент; Н - максилла. Масштаб: А -100 мкм; В-Н -50 мкм. 
sipodite simple, leuckarti-like, shown in Fig. 8D, E.

P1 basipodite without medial spine. P4 intercoxal sclerite with two large sharp outgrowths. Coxopodite with few small denticles on distal edge, coxopodite seta noticeably longer that basipodite inner outgrowth height. Basipodite inner outgrowth with short, distally placed hairs. P4 Enp3 L/ W 2.6, inner spine about 0.8 as long as segment, and equal to outer spine or slightly longer.

P5 with three setae, relative lengths of which from inner to outer: $1.0 / 1.1 / 0.9$.

DIFFERENTIAL DIAGNOSIS. This species can be easily distinguished from other Mesocyclops of Russian fauna by presence of hairs on Th4 and inner margin of caudal rami, due to which its belongs to subgenus Pilosomesocyclops. The only representative of this subgenus noted for Russia is M. dissimilis Defaye et Kawabata, 1993, which is missing hairs on inner margin of caudal rami and has strongly curved copulatory duct of receptaculum seminis.

DATE AND PLACE OF FINDINGS: Primorsky Krai, Astrakhanka town vicinity, $100 \mathrm{~m}$ from the shore of Lake Khanka, irrigation reservoir on territory of the tourist base

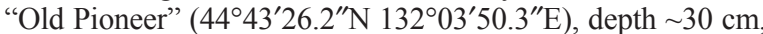
14 August 2019. The sample contained 2 우 with egg sacks.

DISTRIBUTION. Described from Southern China [Guo, 2000], M. mariae was found in small numbers near Lake Khanka of Far East of Russia.

\section{Mesosyclops (Pilosomesocyclops) dissimilis Defaye et Kawabata, 1993}

Fig. 9.

MORPHOLOGICAL DESCRIPTION. Female body length without caudal setae $1040-1300 \mu \mathrm{m}$. Th4 with sparse lateral hairs. Receptaculum seminis with wide, curved lateral arms, proximal part sinuate in middle, transverse ducts meeting at sharp angle, copulatory duct long and thin, strongly curved laterally. Caudal rami L/W ratio $3.1-3.8$, slightly divergent, with bare inner margin. Small spinules at places of insertion of lateral and outermost setae. All caudal setae plumose. Lateral seta longer than ramus length. Dorsal seta $1.0-1.5$ times as long as outermost seta. Relative lengths of caudal setae beginning from outermost: 1.0/ 3.5-3.8/5.5-6.5 12.5-2.8.

Antennule (A1) 17-segmented, last two segments bear wide hyaline membrane with one notch, ventral surface of most antennular segments covered with spinules. Antenna (A2) second endopodite segment with 7 setae, basipodite frontal surface in addition to simple, leuckarti-like pattern, bears several distal spinules at the base of medial setae (Fig. 9D).

P1 basipodite without medial spine. P4 intercoxal sclerite with two very low triangular outgrowths, usually blunt or sometimes with sharp tip. Coxopodite seta noticeably longer that basipodite inner outgrowth height (sometimes almost twice as long). P4 Enp3 L/W 2.8-3.2, inner spine 0.8-0.9 as long as segment, and equal or slightly longer than outer spine.

P5 with three setae, apical seta very long, usually significantly exceeding inner spine and reaching posterior margin of genital somite.

DIFFERENTIAL DIAGNOSIS. $M$. dissimilis is easily distinguishable from other Mesocyclops of Russia by presence of weak, sparse lateral hairs on T4, strongly curved copulatory duct of receptaculum seminis and low outgrowths on P4 intercoxal sclerite.
DATE AND PLACE OF FINDINGS: Primorsky Krai :

1. Vladivostok, Minnye Lakes $\left(44^{\circ} 44^{\prime} 49.9^{\prime \prime} \mathrm{N} 132^{\circ} 03^{\prime}\right.$ 21.4"E), 13 August 2019, 16우.

2. Astrakhanka, Lake Khanka, pier, $3 \mathrm{~m}$ depth, $50 \mathrm{~m}$ from shore $\left(44^{\circ} 43^{\prime} 26.3^{\prime \prime} \mathrm{N} 132^{\circ} 03^{\prime} 58.8^{\prime \prime} \mathrm{E}\right), 14$ August 2019, 2 우오.

3. Astrakhanka, Lake Khanka, $25 \mathrm{~m}$ along shore, $1 \mathrm{~m}$

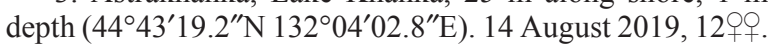

4. Kamen-Rybolov, Lake Khanka, bay, small port $\left(44^{\circ} 44^{\prime} 49.9^{\prime \prime} \mathrm{N} 132^{\circ} 03^{\prime} 21.4^{\prime \prime} \mathrm{E}\right)$, at depth of $10-15 \mathrm{~cm}$, among floating vegetation, 14 August 2019, 3우. The sample contained 6 우 of M. pehpeiensis as well.

5. Russkiy Island, a pond on the territory of the Far Eastern federal university $\left(43^{\circ} 01^{\prime} 50.0^{\prime \prime} \mathrm{N} 131^{\circ} 53^{\prime} 38.6^{\prime \prime} \mathrm{E}\right)$, at depth $\sim 1.5 \mathrm{~m}, 17$ August 2019, 11 웅.

6. Vladivostok, mouth of Bogataya river, at Brazhnikov Bay, depth about $1 \mathrm{~m}\left(43^{\circ} 14^{\prime} 30.2^{\prime \prime} \mathrm{N} 132^{\circ} 00^{\prime} 41.8^{\prime \prime} \mathrm{E}\right), 20$ August 2019, 12 우.

DISTRIBUTION. Described from Lake Biwa of Japan [Defaye, Kawabata, 1993] it was reported from China, Vietnam, and apparently is widely distributed in the Primorsky Krai. In Russia, this species has been previously noted for Khanka Lake [Alekssev, Barabanshchikov, 2006].

\section{Mesocyclops (Mesocyclops) pehpeiensis $\mathrm{Hu}, 1943$}

Fig. 10.

MORPHOLOGICAL DESCRIPTION. Female body length without caudal setae 1181-1645 $\mu \mathrm{m}$. Th4 bare. Receptaculum seminis with wide, long, curved lateral arms, proximal part slightly sinuate in middle, transverse ducts meeting at sharp angle, copulatory duct long and thin, curved laterally. Caudal rami L/W ratio 3.4-3.8, slightly divergent, with bare inner margin. Small spinules at places of insertion of lateral and outermost setae. All caudal setae plumose. Lateral seta longer than ramus length. Dorsal seta $0.8-1.0$ times as long as outermost seta. Relative lengths of caudal setae beginning from outermost: 1.0/ 3.8-4.6/5.2-6.3/2.42.9 .

Antennule (A1) 17-segmented, reaching posterior edge of second free thoracic somite; last two segments bear wide hyaline membrane with one notch. Antenna (A2) second endopodite segment with 7 setae, basipodite frontal surface in addition to simple, leuckarti-like pattern, bears few spinules at the base of medial setae (Fig. 10D).

P1 basipodite without medial spine. P4 intercoxal sclerite with two long outgrowths, triangular or finger-shaped. Coxopodite seta noticeably longer that basipodite inner outgrowth height. Basipodite inner outgrowth bare. P4 Enp3 L/ W 2.5-3.3, inner spine $0.8-0.9$ as long as segment, and slightly longer than outer spine.

P5 with three setae, relative lengths of which from inner to outer: $1.0 / 1.1-1.3 / 0.5-0.7$.

DIFFERENTIAL DIAGNOSIS. M. (M.) pehpeiensis most resembles $M$. (M.) leuckarti (Claus, 1857) in appearance and presence of long, often finger-shaped outgrowths on P4 intercoxal sclerite, but can be distinguished by long and curved copulatory duct of receptaculum seminis, and absence of hairs on inner outgrowth of $\mathrm{P} 4$ basipodite.

DATE AND PLACE OF FINDINGS: 1. Primorsky Krai, Kamen-Rybolov, Lake Khanka, bay, small port $\left(44^{\circ} 44^{\prime}\right.$ $49.9^{\prime \prime} \mathrm{N} 132^{\circ} 03^{\prime} 21.4^{\prime \prime} \mathrm{E}$ ), at depth of $10-15 \mathrm{~cm}$ by hand net, among floating vegetation, 14 August. The sample contained 6 우 of M. pehpeiensis together with 9 9 9 of M. dissimilis. 

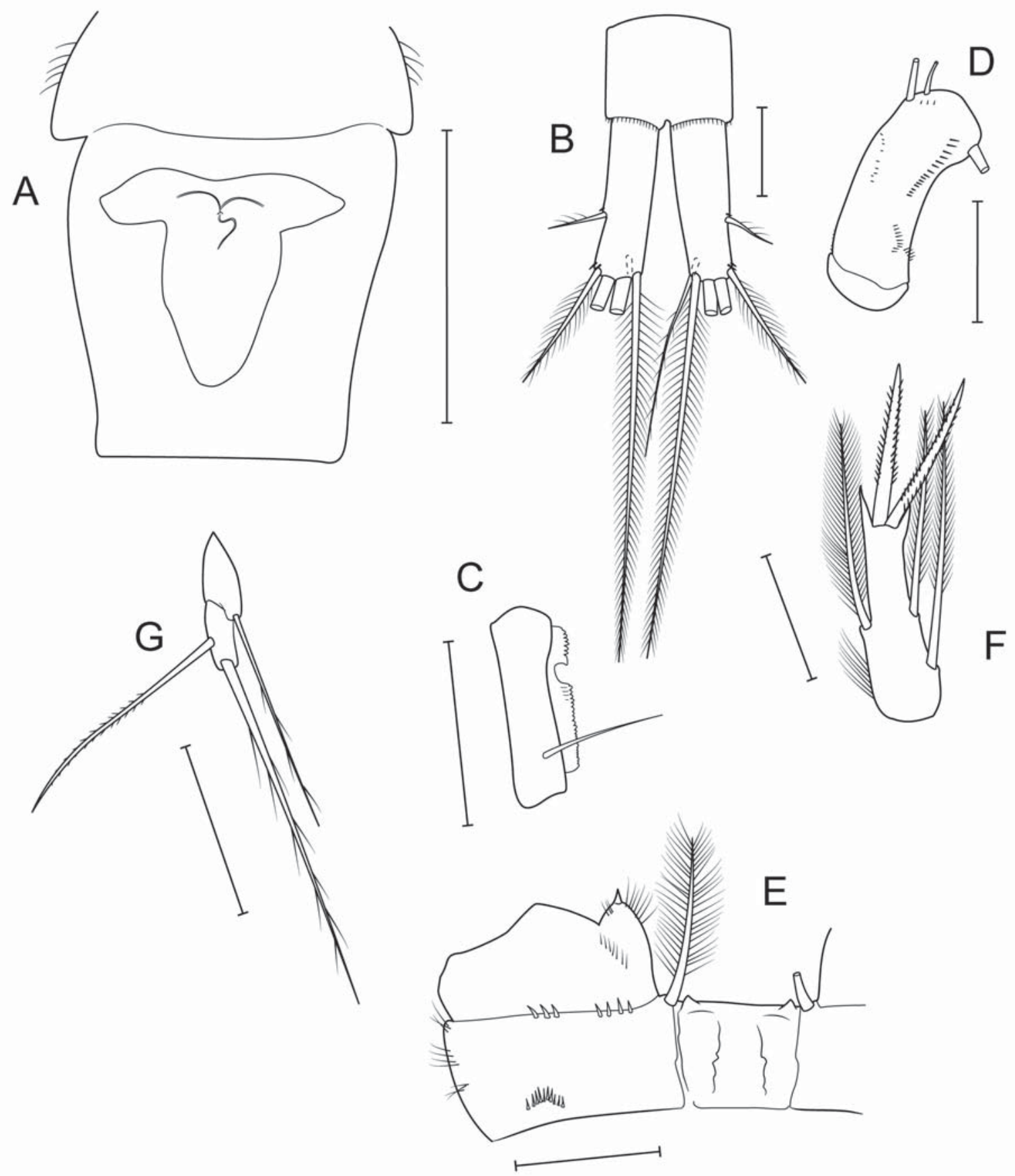

Fig. 9. Mesocyclops (Pilosomesocyclops) dissimilis Defaye et Kawabata, 1993, + . A — genital double somite; B — caudal rami, ventral; C - antennule (A1), distal segment; D - antenna (A2), frontal; E - P4; F - P4 endopodite, distal segment; G - P5. Scale bars: $\mathrm{A}-100 \mu \mathrm{m} ; \mathrm{B}-\mathrm{G}-50 \mu \mathrm{m}$.

Рис. 9. Mesocyclops (Pilosomesocyclops) dissimilis Defaye et Kawabata, 1993, ๆ. А - генитальный сегмент; В - каудальные ветви, вентрально; С — антеннула (А1), дистальный сегмент; D - антенна (А2), фронтально; Е — P4; F — Р4 эндоподит, дистальный сегмент; $\mathrm{G}-\mathrm{P} 5$. Масштаб: А - 100 мкм; B-G - 50 мкм.

2. Primorsky Krai, Bogataya river within the city of Vladivostok, $100 \mathrm{~m}$ from the confluence with the Brazhnikov Bay $\left(43^{\circ} 14^{\prime \prime} 28.8^{\prime \prime} \mathrm{N} 132^{\circ} 0 " 47.7^{\prime \prime} \mathrm{E}\right)$, at depth of $\sim 1.5 \mathrm{~m}$, from bridge, 20 August 2019, 4우.

DISTRIBUTION. Widespread in China, from where it was described [Hu, 1943]. Reported as well from Japan, Central Asia, India, Sri Lanka, Vietnam [Holynska, 2003].
In 1981 Kiefer found it and described as "M.ruttneri" in Austria. Some finds of M. ruttneri Kiefer, 1981 (= M. pehpeiensis) were recorded in Kazakhstan, Uzbekistan [Mirabdullayev et al, 1995; Mirabdullayev, 1996], and in the southern United States [Reid, 1993]. M. pehpeiensis was recently found in Mexico, Spain, Crimea [Anufriieva et al., 2014; Montoliu et al., 2015]. 

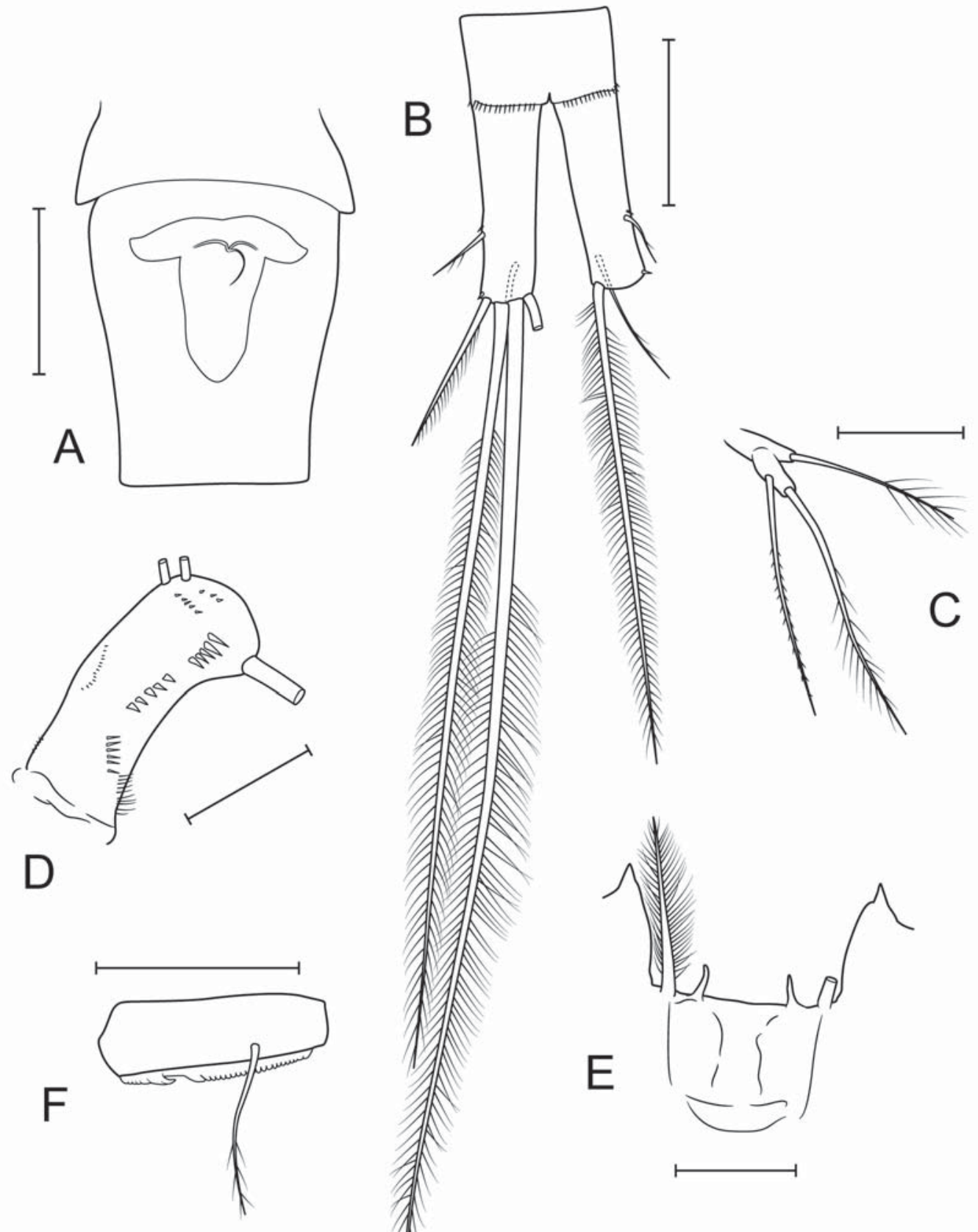

Fig. 10. Mesocyclops (Mesocyclops) pehpeiensis Hu, 1943, ‥ A - genital double somite; B - caudal rami, ventral; C - P5; D antenna (A2), frontal; E - P4, intercoxal sclerite; F — antennule (A1), distal segment. Scale bars: A, B - $100 \mu \mathrm{m}$; C-F - $50 \mu \mathrm{m}$.

Рис. 10. Mesocyclops (Mesocyclops) pehpeiensis Hu, 1943, ․ А - генитальный сегмент; В — каудальные ветви, вентрально; C - P5; D - антенна (А2), фронтально; Е — Р4 межкоксальная пластинка; F — антеннула (А1), дистальный сегмент. Масштаб: $\mathrm{A}, \mathrm{B}-100$ мкм; $\mathrm{C}-\mathrm{F}-50$ мкм. 


\section{Discussion}

According to their genesis and significance, new finds can be divided into several groups:

(1) Described from this zoogeographic region, but not noted previously for the territory of Russia. Most of the described forms belong to this group. From it, it is necessary to distinguish Ectocyclops polyspinosus, which $\mathrm{V}$. Rylov undoubtedly met, indicating the variation in the number of antennule segments in E. phaleratus from the eastern regions of the USSR [Rylov, 1948]. At that time, E. polyspinosus had not yet been described and, accordingly, could not be recorded for our fauna.

Eucyclops $(S$.) dumonti was described from a small lake associated with a spring in the Central Mongolia. Later it was found in small lakes between sand dunes in North China, as well as in the river Tatsin, flowing into the lake of the same name [Alekseev, 2019]. All these three locations are geographically rather close. It is noteworthy that in two cases out of three this species was found in the places where groundwater exits.

Two new for Russian fauna species of Mesocyclops - M. (P.) mariae, M. (M.) dissimilis, - were described from this zoogeographic region of Southeast Asia and undoubtfully were previously confused, when being identified, with the only noted for fauna of the Russian Far East M. (M.) leuckarti. It should be noted that the latter species was encountered by us in samples from the water bodies of the Far East only once - in the plankton of a small lake on Russky Island (vicinity of Vladivostok), while the most widespread species of this genus was $M$. $(P$.$) dissimilis. It is quite possible$ that $M$. (M.) leuckarti in this region is an invasive and still rare species, thereby all previous indications of its findings should be rechecked.

(2) Species with a latitudinal range of an eastern direction. These species include the Megacyclops magnus described from the lakes of Canada. Only recently has it been found in Japan [Ishida, 2002] and on the Korean Peninsula [Lee et al., 2007]. Judging by the finds, the species in Asia lives in the coastal regions of the North Pacific, where it was most likely previously mixed with $M$. viridis of a similar size.

(3) Species with a latitudinal range of a western direction, often interrupted as in Tropocyclops prasinus (Fischer, 1860), which in our country is known from the reservoirs of the south of the European region and the Primorsky Krai [Monchenko, 1974]. Of those found for the first time, this group includes $E$. $(E$. agiloides and E. (D.) euacanthus. Both taxa belong to a rather large group of pan-tropic species of the Old World. Representatives of this group were often found in isolated with young mountains and / or island areas. This commitment to the formation of isolated habitats suggests a connection with the movement of the earth's crust and the historical basis of modern habitats. It can be assumed that the current boundaries of the distribution of species of this group are dependent on the fauna of the final phase of the existence of the Tethys Sea, which closed in the geologically recent past due to the joining of the African and Indian continental plates to Eurasia.

(4) Species expanding their range to the north, due to climatic changes, bioinvasion of anthropogenic genesis. We include among such forms M. (M.) pehpeiensis, which is currently actively expanding its range and was recently found in the Crimea, Spain and even Mexico, and is everywhere attributed as an invasive form. Although this species has been described from this region of Southeast Asia, but much more south, and its finding in the Ussuri krai in a small number so far probably reflects its movement to the north due to climate warming. Judging by the first finds outside the historical range (temporary reservoirs, ponds often not connected with river networks) in the distribution of this species, waterfowl migrating birds play a role. There is a very high probability of finding it along the migratory routes of waterfowl in the East of Russia, primarily in Kamchatka and Sakhalin. In the European part after Crimea, the river systems of the Don and Volga will probably become new places of finds of this species.

Most of the species found new to Russia can be identified using the recently published keys of genera Eucyclops [Alekseev, 2019] and Mesocyclops [Alekseev, 2020] of the world fauna.

Two species of the genus Ectocyclops known from the water bodies of Russia, as indicated above, easily diverge in the number of antennule segments.

Described from Canada and recently found in Asia, Megacyclops magnus can be reliably identified using a characteristic unique for this genus - the length of the inner spine of the P4 endopod, which is shorter than the outer spine.

Finally, to identify a representative of the genus Cyclops new to the Russian fauna, it is advisable to use the recently published key of this genus [Holynska, Dimante-Deimantovica, 2016].

Acknowledgments. We express our gratitude to our colleagues who kindly sent the material: Dr. Tatiana Vshivkova (Institute of Biology and Soil Science, Far East Center of the Russian Academy of Science), Dr. Natalya Sheveleva (Limnological Institute of the Russian Academy of Sciences) and Prof. Henry Dumont (University of Ghent, Belgium), as well as to all participants of our expeditions. This work was supported by RSF grant 20-04-00035 and the Federal Program for Studying the Biodiversity (project no. AAAA-A19119020690091-0) by Russian Academy of Sciences.

\section{References}

Alekseev V.R. 1998. Key to freshwater Cyclopidae of Russia and adjacent lands (Crustacea) // Zoosystematica Rossica. Vol.7. P.25-43.

Alekseev V.R. 2000. Eucyclops dumonti sp. nov. from Central Mongolia // Hydrobiologia. Vol.441. P.63-71.

Alekseev V.R. 2015. [Copepoda] // Opredelitel' ryb i bespozvonochnykh Kaspiyskogo morya. Vol.2. SPb.-Moscow: KMK Scientific Press. P.39-192 [in Russian]. 
Alekseev V.R. 2019. Revision of the genus Eucyclops (Claus, 1893) and subfamily Eucyclopinae of the world fauna // Arthropoda Selecta. Vol.28. No.4. P.490-514.

Alekseev V.R. 2020. [Revision of the genus Mesocyclops Sars 1914 (Copepoda. Cyclopidae) of the world fauna] // Zoologicheskii Zhurnal. Vol.99. No.12. P.1323-1344 [in Russian].

Alekseev V.R., Barabanshchikov E.I. 2006. [A species of the genus Mesocyclops (Cyclopoida, Copepoda) from Lake Khanka new for the Russian fauna]// Zoologicheskii Zhurnal. Vol.85. No.10. P.1257-1260 [in Russian].

Anufriieva E., Hołyńska M., Shadrin N. 2014. Current invasions of Asian Cyclopid species (Copepoda: Cyclopidae) in Crimea, with taxonomical and zoogeographical remarks on the hypersaline and freshwater fauna // Annales Zoologici PAN. Vol.64. No.1. P.109-130.

Defaye D., Kawabata K. 1993. Mesocyclops dissimilis n. sp. from Lake Biwa, Japan (Copepoda, Cyclopoida) // Hydrobiologia. Vol.257. No.2. P.21-126.

Dussart B., Defaye D. 2006. World Directory of Crustacea Copepoda of Inland Waters, II - Cyclopiformes. Leiden: Backhuys. $354 \mathrm{p}$

Einsle U. 1993. Megacyclops magnus (Marsh, 1920) (Crustacea, Copepoda) in northern Canada, a comparison with European Megacyclops species // Canadian Journal of Zoology Vol.71. No.7. P.1434-1438.

Einsle U. 1996. Cyclops heberti n. sp. and Cyclops singularis $\mathrm{n}$. sp., two new species within the genus Cyclops ("strenuussubgroup") (Crust. Copepoda) from ephemeral ponds in southern Germany // Hydrobiologia. Vol.319. No.3. P.167-177.

Guo X.M. 2000. Two new species of Mesocyclops from southern China and notes on the genus Mesocyclops in China // Hydrobiologia. Vol.429. P.115-131.

Harada I. 1931. [Studies on the freshwater fauna of Formosa. - IV On the Cyclopidae of Fromosa] // Dobuts Zasshi. Tokyo. Vol. 43. P.226-236 [in Japanese].

Holynska M. 2003. Genus Mesocyclops Sars, 1914 // Reid J.W., Ueda H. (eds.). Copepoda: Cyclopoida. Genera Mesocyclops and Thermocyclops. Guides to the Identification of the Microinvertebrates of the Continental Waters of the World. Vol.20. P.12-213.

Holynska M., Dahms H.U. 2004. New diagnostic microcharacters of the cephalothoracic appendages in Cyclops OF Müller, 1776 (Crustacea, Copepoda, Cyclopoida) // Zoosystema. Vol.26. No.2. P.175-198.

Holynska M., Dimante-Deimantovica I. 2016. Redescription and taxonomic notes on Cyclops bohater KoŸmiñski, 1933 and Cyclops lacustris GO Sars, 1863 (Arthropoda, Crustacea), with an identification key to the Cyclops species of Fenno-Scandinavia // European Journal of Taxonomy. Vol.212. DOI: 10.5852/ ejt.2016.212

Holynska M., Slugocki L., Ghaouaci S., Amarouayache M. 2021. Taxonomic status of Macaronesian Eucyclops agiloides azorensis (Arthropoda: Crustacea: Copepoda) revisited - morphology suggests a Palearctic origin // European Journal of Taxonomy. Vol.750. P.1-28.

Holynska M., Wyngaard G.A. 2019. Towards a phylogeny of $C y$ clops (Copepoda):(in) congruences among morphology, molecules and zoogeography // Zoologica Scripta. Vol.48. No.3.
P.376-398.

$\mathrm{Hu}$ Y.T. 1943. Notes on fresh-water copepods from Pehpei, Szechwan // Sinensia. Vol.14. P.115-128.

Ishida T. 1997. Eucyclops roseus, a new Eurasian copepod, and the E. serrulatus-speratus problem in Japan // Japanese Journal of Limnology. Vol.58. No.4. P.349-358.

Ishida T. 2002. [Illustrated fauna of the freshwater cyclopoid copepods of Japan] // Bulletin of the Biogeographical Society of Japan. Vol.57. P.37-106 [in Japanese].

Kiefer F. 1978. Freilebende Copepoda // Elster H.-J., Ohle W. (Hrsg.). Das Zooplankton der Binnengewässer 2. Teil. Stuttgart: Schweizerbart'sche Velagsbuchhandlung. S.1-34.

Lee J.M., Kim W.R., Choi Y.G., Chang C.Y. 2007. Four Cyclopoid Species (Copepoda: Cyclopidae) from Limestone Caves and Lava Tube in South Korea // Animal Systematics, Evolution and Diversity. Vol.23. No.2. P.155-167.

Lindberg K. 1956. Courtes diagnoses de quelques membres nouveaux ou peu connus du genre Cyclops s. str. // Bolletino della Società Entomologica Italiana. Vol.86. P.112-117.

Marsh C.D. 1920. Report of the Canadian Arctic Expedition 191318. Crustacea, Freshwater Copepoda // Report Canad. Arct. Exp. Vol.7. P.1-25.

Mazepova G.F. 1978. [Cyclops of Lake Baikal]. Novosibirsk: Nauka Publ. 143 p. [In Russian]

Mirabdullayev I.M, 1996. The genus Mesocyclops (Crustacea: Copepoda) in Uzbekistan (Central Asia) // Internationale Revue der gesamten Hydrobiologie und Hydrographie. Vol.81. No.1. P.93-100.

Mirabdullayev I.M., Stuge T.S., Kuzmetov A.R., 1995. On Mesocyclops ruttneri Kiefer, 1981 a species new to Kazakstan // Selevinia. Vol.2. P.31-32.

Monchenko V.I. 1974. [Gnathostome cyclopoids (Cyclopidae)] // Fauna Ukrainy. Kyiv: Naukova Dumka. Vol.27. No.3. 452 p. [In Ukranian]

Monchenko V.I. 2003. [Free-living cyclopiform copepods of the Ponto-Caspian Basin]. Kyiv: Naukova Dumka. 350 p. [In Ukranian]

Montoliu L., Miracle M.R., Elías-Gutiérrez M. 2015. Using DNA barcodes to detect non-indigenous species: the case of the Asian copepod Mesocyclops pehpeiensis Hu, 1943 (Cyclopidae) in two regions of the world // Crustaceana. Vol.88. No.1214. P.1323-1338.

Reid J.W. 1993. New records and redescriptions of American species of Mesocyclops and of Diacyclops bernardi (Petkovski 1986) (Copepoda: Cyclopoida) // Bijdragen tot de Dierkunde. Vol.63. No.3. P.173-191.

Rylov V.M. 1948. [Freshwater Cyclopoida] // Fauna SSSR. Rakoobraznye. Vol.3. Leningrad: AN SSSR Publ. 318 p. [In Russian]

Sars G.O. 1909. Report on the Copepoda. Zoological Results of the Third Tanganyika Expedition, conducted by Dr. W.A. Cunnington, F.Z.S., 1904-1905 // Proceedings of the Zoological Society of London. P.31-77.

Yeatman H.C. 1944. American cyclopoid copepods of the viridisvernalis group, (including a description of Cyclops carolinianus n. sp.) //American Midland Naturalist. Vol.32. P.1-90.

Responsible editor K.G. Mikhailov 